\section{Análisis y recuperación de un paisaje urbano fortificado en la villa de Verín (Orense, Galicia)}

\section{Analysis and recovery of an urban fortified landscape in the town of Verín (Orense, Galicia)}

REBECA BLANCO-ROTEA

SONIA GARCÍA-RODRÍGUEZ

ALbERTO Rodríguez-Costas

Anxo Rodríguez Paz

LaPa - Laboratorio de Patrimonio, CSIC. Santiago de Compostela*

\section{Resumen}

La villa de Verín se localiza en el SE de Galicia, muy próxima a la frontera de Portugal y a los pies del castillo de Monterrei. Durante la Guerra de la Restauración Portuguesa (1640-1668) su localización la convierte en un importante enclave defensivo relacionado con la protección del castillo de Monterrei y el paso desde Portugal hacia la provincia de Ourense desde Chaves. La venta de los terrenos de la muralla moderna a mediados del siglo XIX y la fuerte transformación urbanística que sufre en la segunda mitad del siglo Xx, enmascaran su trazado fortificado. A través de los trabajos que aquí se presentan se pretende recuperar el papel que la villa jugó en aquel periodo y las transformaciones que Verín ha ido sufriendo desde época bajomedieval.

Palabras claves: Lectura de Alzados; Fotointerpretación; Prospección arquitectónica; Guerra de la Restauración Portuguesa; Edad Moderna.

\section{Summary}

The town of Verín is situated in south-eastern Galicia, very close to the frontier with Portugal and at the feet of Monterrei Castle. During the Portuguese War of Restoration (1640-1668), because of its position, it was an important defensive enclave related to the defence of Monterrei Castle and the road leading from Portugal towards the province of Ourense from Chaves. The fortified outline is hidden by the sale of the land on which the modern walls stood in the middle of the $19^{\text {th }}$ century and the large-scale urban development of the second half of the $20^{\text {th }}$ century. The aim of this work is to know what role Verín played during these periods and its transformations since the Late Middle Ages.

Key words: Elevation Readings; Photointerpretation; Architectural Prospecting; Portuguese War of Restoration; Modern Age.

\footnotetext{
* rebeca.blanco-rotea@iegps.csic.es sonia.garcia-rodriguez@iegps.csic.es alberto.rodriguez-costas@iegps.csic.es anxo.rodriguez-paz@iegps.csic.es
}

\section{INTRODUCCIÓN}

Cuando en el año 2005 la Dirección Xeral de Patrimonio Cultural (DXPC), entonces dependiente de la Consellería de Cultura, Comunicación e Turismo de la Xunta de Galicia, encargaba al Laboratorio de Patrimonio (en adelante $\mathrm{LaPa}$ ) - CSIC el estudio de los posibles restos de un baluarte en un solar de la Villa de Verín, no podíamos suponer lo que los resultados de este estudio iban a aportar al conocimiento de la historia de la Villa.

En este solar, se había planteado la demolición de las estructuras que en él se conservaban: un edificio de dos pisos; una construcción dedicada al procesado y almacenamiento de vino; y unos grandes muros que formaban una estructura de planta pentagonal contra y sobre la que se había construido la bodega y que se consideraban muros de contención, ya que el solar se encontraba a orillas del río Támega, para realizar un edificio de nueva planta.

En este contexto la DXPC promueve la realización de un exhaustivo estudio de dichas construcciones que, inicialmente, incluía varios sondeos arqueológicos, el levantamiento volumétrico del conjunto, la lectura de alzados, así como un vaciado de fuentes históricas y bibliográficas ${ }^{1}$.

Los objetivos de la intervención podían resumirse en: documentar y registrar las estructuras arquitectónicas y arqueológicas; analizar su técnica constructiva, secuencia constructiva y funcionalidad; datar las estructuras; e intentar delimitar el conjunto fortificado en su entorno inmediato.

Sobre los muros del posible baluarte existía el precedente del estudio realizado en los años 40 del siglo XX por Xesús Taboada Chivite (1949), quien ya había apuntado que estos formarían parte de la fortificación de la villa de Verín y serían en concreto un baluarte de la misma.

Este mismo investigador propone el trazado de la muralla (TABOADA ChIVITE, 1949) que, partiendo de dicho baluarte ${ }^{2}$, circunscribe lo que actualmente se considera el casco histórico de la villa, aunque ampliándolo por el E, el NW y el lado N, con un trazado prácticamente rectangular cuyo lado más largo se orientaría en sentido EW. Para esta propuesta se basó en los escasos restos conservados de esta posible fortificación, en la toponimia,

\footnotetext{
${ }^{1}$ Ficha Técnica: Investigador Responsable: Felipe Criado Boado; Dirección de la actuación: Rebeca Blanco Rotea; Ayudante de Dirección: Sonia García Rodríguez; Equipo Técnico: Noemí Calvo Valcarce, Cristina Cancela Cereijo; Topografía: Miguel Grueiro Méndez; Fotografía: Sonia García Rodríguez, Rebeca Blanco Rotea; Delineación: Anxo Rodríguez Paz, Sonia García Rodríguez, Alberto Rodríguez Costas; Estudio y procesado de la Cultura Material: Cristina Cancela Cereijo; Tratamiento de la información: Matilde Millán Lence; Estudio de la litología de la muralla: Manuela Costa Casais.

${ }^{2}$ El único que se localiza en este trazado.
} 


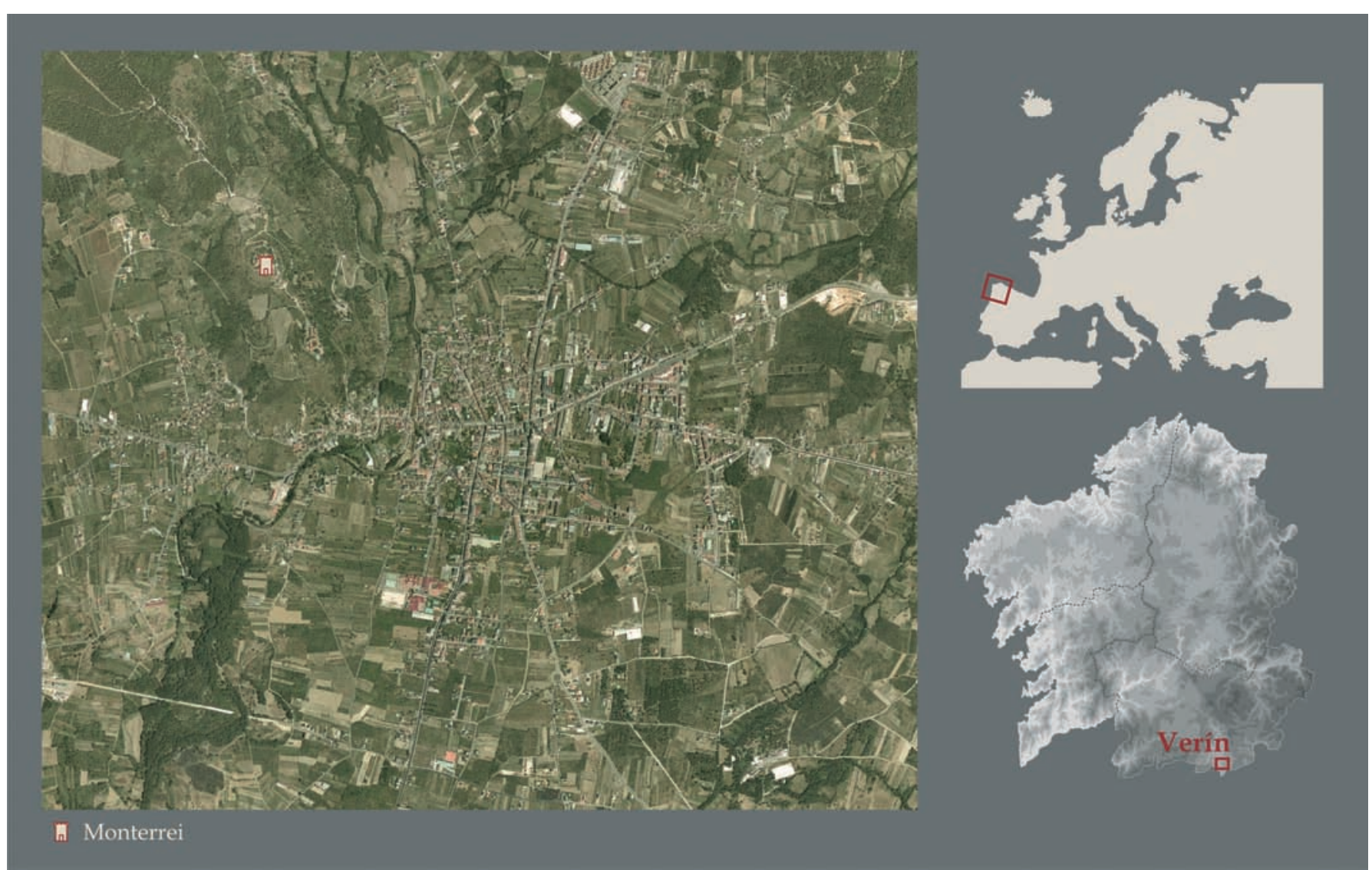

Fig. 1. Situación de la Villa de Verín y el Castillo de Monterrei

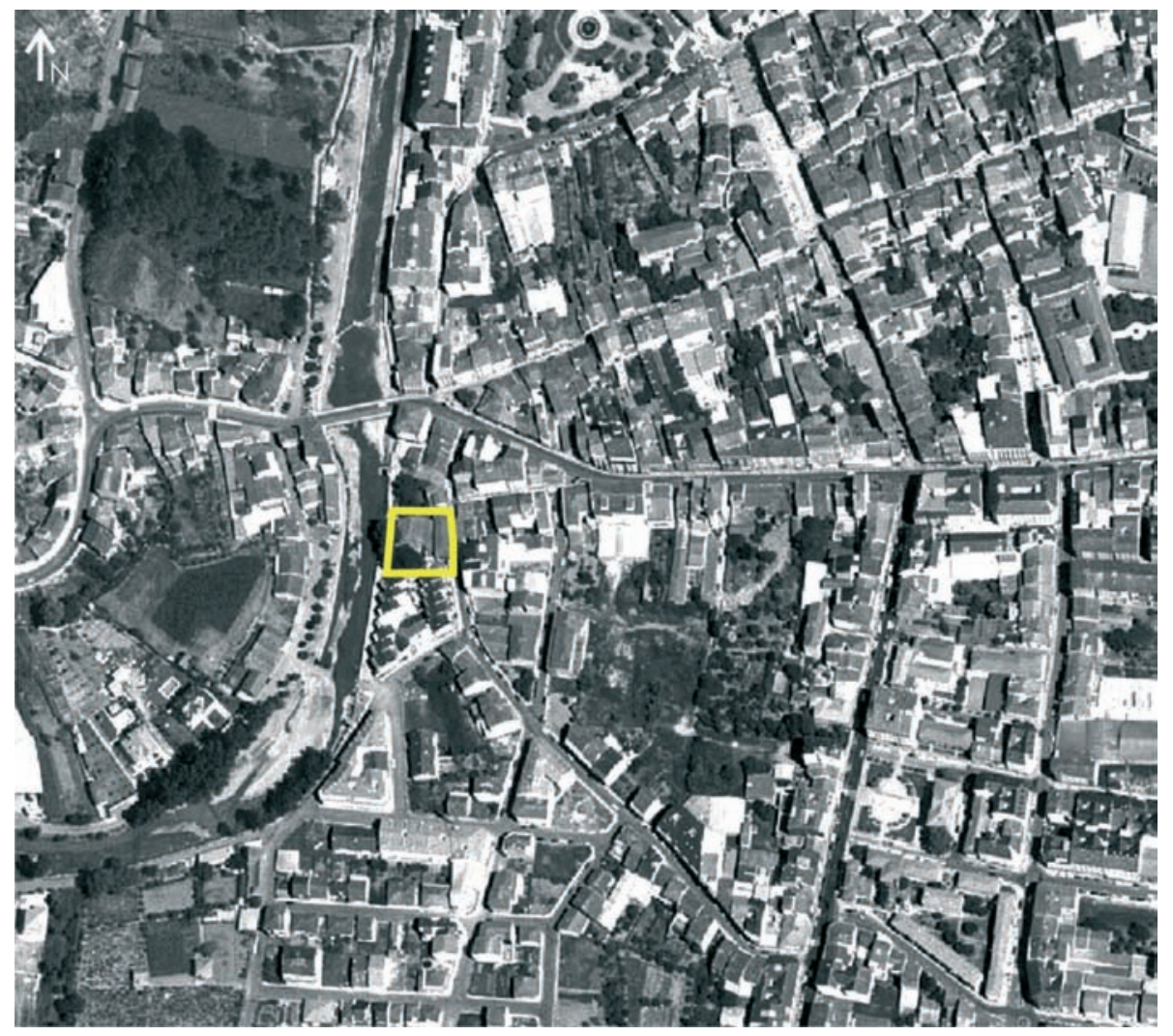

Fig. 2. Ubicación del solar objeto de la intervención 
Fig. 3. Plano de Verín, publicado por Taboada Chivite (1949), en el que se representa en línea de puntos el posible trazado de la muralla y el Baluarte de la Calle

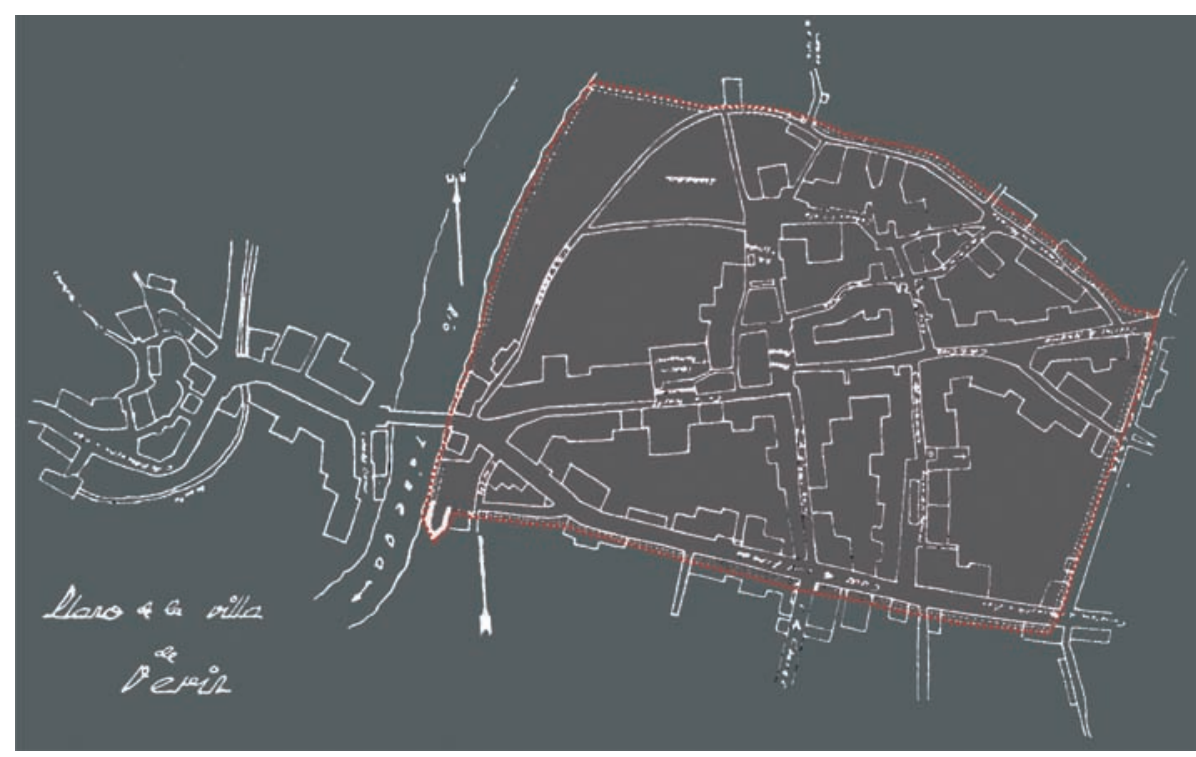

en la memoria oral de los vecinos y en algunos textos a los que tuvo acceso en su día.

Una vez comenzados los trabajos, decidimos aplicar una estrategia de investigación más ambiciosa con la intención de maximizar la información que poco a poco se iba generando, ampliando las propuestas de actuación inicialmente planteadas ${ }^{3} \mathrm{y}$ diseñando una nueva estrategia de trabajo, bajo la cual se aplicaron al estudio las siguientes metodologías:

- Levantamiento planimétrico de todo el conjunto arquitectónico localizado en el interior del solar, paso previo necesario para poder documentar y registrar los elementos constructivos. Este levantamiento contribuiría a la conservación de las estructuras, al menos de forma gráfica. Se llevó a cabo empleando una estación total topográfica láser.

- Sondeos arqueológicos encaminados a recuperar la secuencia estratigráfica exterior e interior del baluarte, determinar su adscripción cronológica, documentar su técnica constructiva y, si existieran, la presencia de otras estructuras previas, coetáneas o posteriores al baluarte.

\footnotetext{
3 Debe tenerse en cuenta que dentro de la Unidad de Arqueología de la Arquitectura del LaPa una de las líneas de investigación que se venía desarrollando desde el año 2003 era el estudio de la fortificación abaluartada en la frontera de la Raya Húmeda (Blanco y García, 2005), así denominada porque se encuadra en la zona en que la frontera entre Galicia y Portugal la constituye el río Miño, y el trabajo sobre la posible fortificación de la villa de Verín, encuadrada en la Raya Seca en la misma época, constituía un interesante ejemplo que permitía comparar los sistemas fortificados adoptados en dos territorios tan dispares bajo un objetivo común.
}

- Análisis estratigráfico de alzados de la construcción dedicada a la explotación vitivinícola y los muros identificados como baluarte, con la finalidad de recuperar la secuencia constructiva de ambas estructuras arquitectónicas e interpretar su posible origen.

- Prospección arquitectónica del casco histórico siguiendo el trazado propuesto por Taboada Chivite y los nombres de las calles que podían estar vinculados a la fortificación. La intención era identificar y documentar posibles restos vinculados con la fortificación de la villa.

- Recogida de la microtoponimia y de topónimos que hicieran referencia a la fortificación tanto procedentes de fuentes escritas como orales.

- Estudio crítico de la documentación procedente de fuentes escritas y gráficas, tanto bibliográficas como históricas, que se conservaran sobre Verín. Se vaciaron archivos estatales, regionales, provinciales, municipales y privados.

- Fotointerpretación arqueológica de la fotografía aérea procedente del Vuelo Americano de 1957 y del Vuelo del Instituto Geográfico Nacional de $1985^{4}$ y de imágenes satélite a partir del año 2003 recogidas en el SixPac, Sitga y Google Earth. La intención de

\footnotetext{
${ }^{4}$ Las fotografías aéreas fueron adquiridas en el Centro Cartográfico y Fotográfico del Ejercito del Aire. En el caso del Vuelo Americano se trata de la Hoja de Zona 379. Fecha: 20 de abril de 1957 (10:30 am), Número 38287-38288, serie B, hoja 303. Escala 1:33000 aproximadamente; en el caso del Vuelo del Instituto Geográfico Nacional: Hoja de zona 5424. Fecha: abril 1985 (09:30 am). H.M.N. 303, Pasada K, Números 0001, 0002 y 0003. Escala 1.30000.
} 

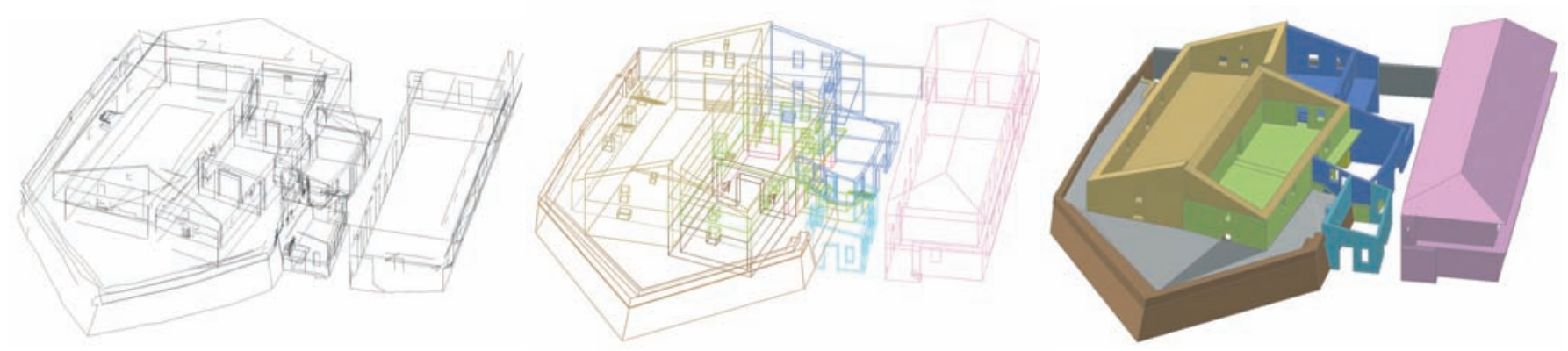

Fig. 4. Proceso de dibujo del levantamiento planimétrico, desde el primer tratamiento digital en CAD hasta la reconstrucción tridimensional

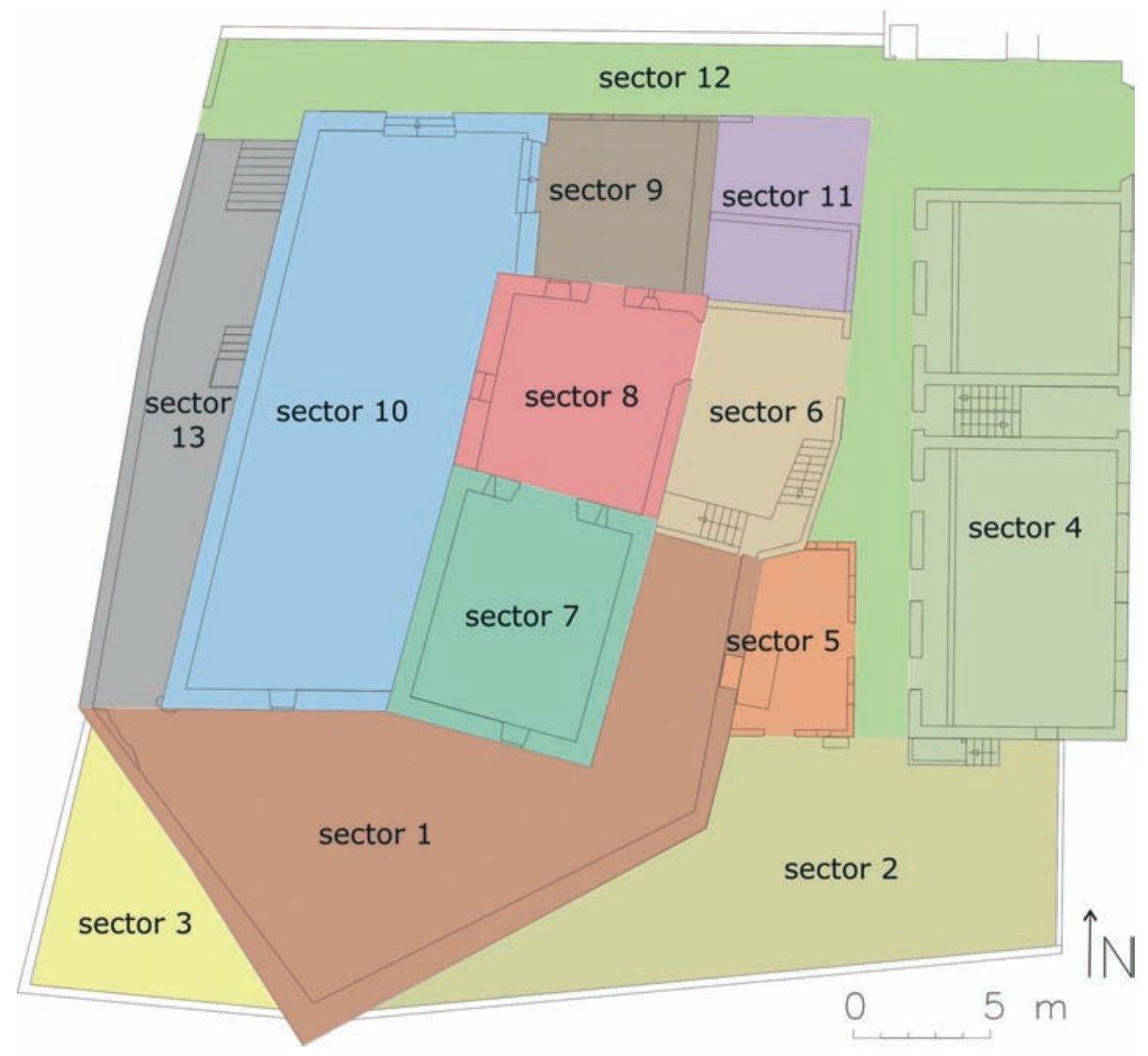

Fig. 5. Sectores de trabajo en los que se dividió el solar

este análisis era conocer la evolución urbanística de la villa y delimitar el recorrido de la fortificación que aparecía mencionada en la documentación de distintas épocas y de la que se conocía únicamente uno de sus baluartes.

\section{EVOLUCIÓN CONSTRUCTIVA DEL SOLAR: DEL TORREÓN A LA EXPLOTACIÓN VITIVINÍCOLA}

La secuencia que a continuación se presenta ha sido identificada gracias a la información extraída de los sondeos y la lectura estratigráfica de alzados. Su datación se ha obtenido gracias a la información recuperada a través del vaciado documental.

\section{Fase I: Época bajomedieval}

Se conservan los restos de un torreón que podría estar relacionado con un sistema defensivo de la villa de Verín, anterior a la construcción de la fortificación abaluartada, o con la existencia de determinados puntos de control en las vías de acceso a Verín. La estancia en la que se localizan estos restos presenta una planta cuadrangular, la única regular de toda la edificación. 


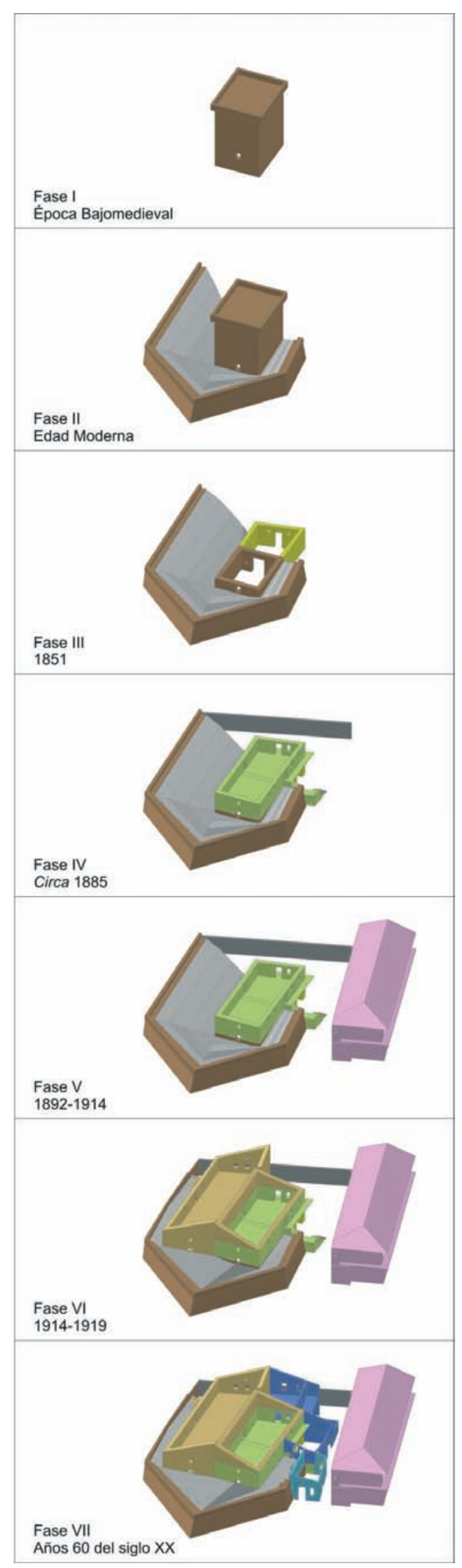

Fig. 6. Reconstrucción tridimensional de las fases identificadas en el solar
La fachada $\mathrm{N}$ que cierra actualmente este espacio contiene dos saeteras, cuya tipología no se corresponde con el tipo de vanos documentados en esta zona en las bodegas $^{5}$. Creemos que podría tratarse de elementos reutilizados de una construcción anterior que, por el tipo de vano de que se trata, posiblemente tuviera una funcionalidad defensiva ${ }^{6}$.

Actualmente la estancia está dedicada a bodega. Resulta interesante la mención que se hace a un torreón en un documento de 1853: "Me conviene igualmente que Don Ramon Santa Marina [...] y desaze si el enrejado de la bodega que cae a la huerta de mi defendida objeto de la cuestion fue denunciado; y que aquella fue construida de cimiento ha un año poco mas o menos sin que antes hubiere alli edificio alguno, y si un torreon. [...]" ${ }^{7}$. En este documento se hace mención a que la bodega se construye en los años 50 del siglo XIX y que antes existía en esta finca un torreón.

A pesar del vaciado documental realizado, no se ha localizado ninguna información sobre la existencia de un sistema defensivo en Verín en época bajomedieval. Sin embargo, varios han sido los hechos que han llevado a plantear la hipótesis de que en esta época podría existir algún tipo de sistema defensivo o bien algún punto de control, como podía ser la figura de los torreones.

Pereira ${ }^{8}$ define varios tipos de torre, para este caso sería interesante tener en cuenta dos de los que apunta, la torre como elemento aislado protegiendo el acceso a puentes o como parte de un conjunto de elementos defensivos.

En el caso de la torre formando parte de un conjunto defensivo, no se han localizado evidencias materiales ni documentales que hablen de la existencia de un amurallamiento en Verín en época bajomedieval. Pero sí se cuenta con alguna evidencia para el caso de torres aisladas defendiendo el acceso a Verín desde el barrio de San Lázaro, o lo que es lo mismo, su comunicación con Monterrei, a través

5 Fundamentalmente bufardas o troneras.

${ }^{6}$ Nos estamos refiriendo al torreón identificado dentro de esta fase.

7 1851-1855, Documentación del proceso de litigio: Demanda del Licenciado Don Ramon Santa Mariña vecino de Verin contra Doña Estrella Noboa sobre construcción de nueva obra en el sitio titulado Elle, del Juzgado del Ayuntamiento de Verín, Archivo particular.

8 «Ao falarmos da torre poderíamos considerar situaçôes distintas: a torre isolada, que está na génese da residência senhorial fortificada [...]; as que protegiam construçôes religiosas [...]; as que protegiam acessos a pontes [...]; e a torre como fazendo parte de um conjunto de elementos defensivos. [...] Por isso, ao falarmos de torre, devemos ter em conta aquela construçâo militar que, com forma variada, foi um dos mais importantes elementos da fortificaçâo durante a neurobalística. Desde as mais arcaicas, com planta quadrangular, até às mais evoluídas, com planta poligonal ou circular, a torre, sobresaindo das muralhas da fortificaçâo, teve, até ao século XVI, um importante papel nos sistemas e conceitos defensivos» (Pereira, 1994: 35). 


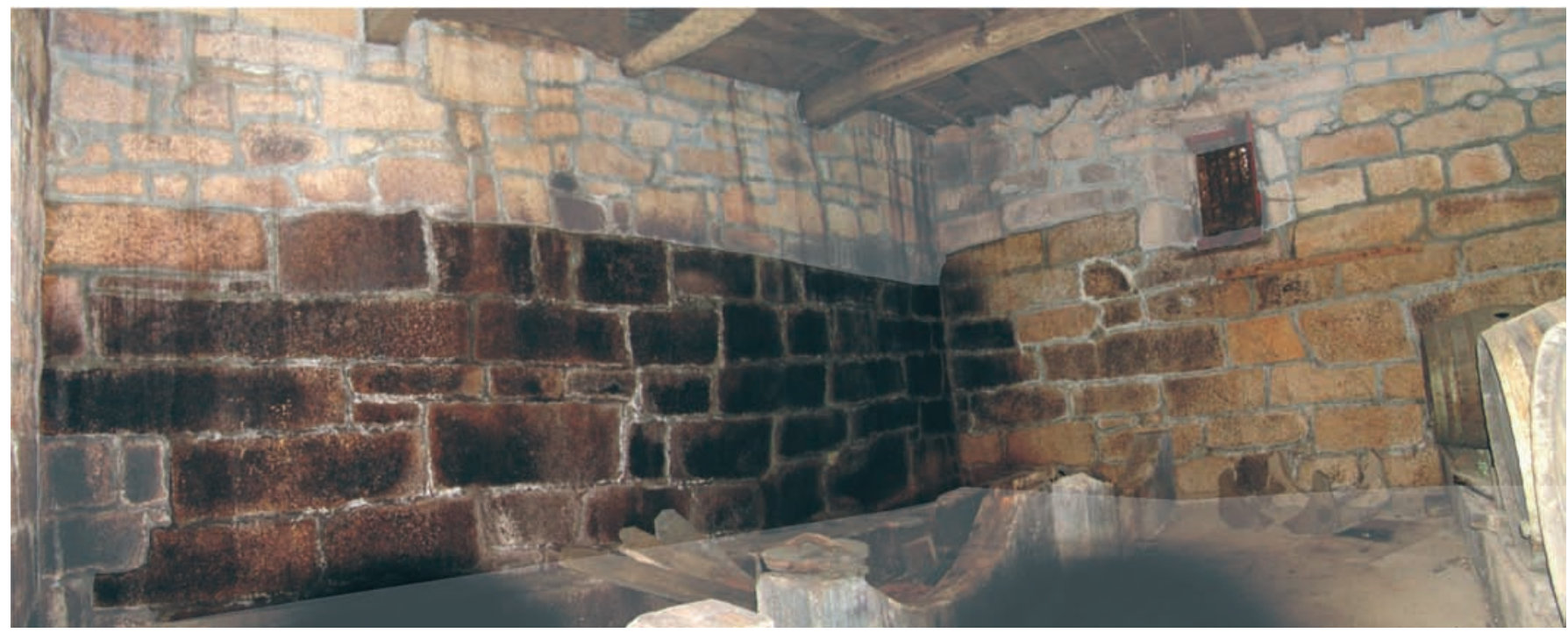

Fig. 7. Restos del torreón bajomedieval identificados en el sector 7

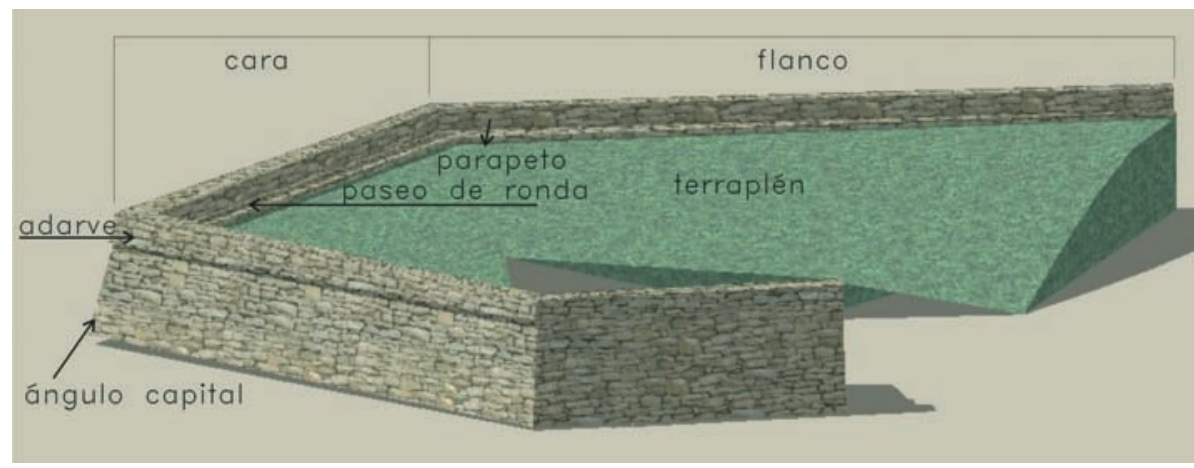

Fig. 8. Partes de un baluarte, sobre la reconstrucción tridimensional del baluarte de la Calle de Elle

de un puente, o en su defecto una puerta de acceso a la villa. Además de los restos de este torreón documentado dentro del solar y de la referencia que a él se hace en el documento del año 1853 , se ha identificado durante la prospección un muro que contiene una saetera, del que se hablará posteriormente, y que podría, por su proximidad, estar relacionado con éste (ver figura 13).

Además, en otros puntos de la villa se recogen referencias al topónimo torre, concretamente uno de ellos se localizaría contiguo a las Puertas de Madrid. En todo caso, la torre como elemento defensivo es anterior al sistema de fortificación abaluartada, es decir, mientras la torre es un elemento fundamental en la fortificación neurobalística, el baluarte lo es en la pirobalística. Por lo tanto, se cree que existen algunas evidencias para plantear la hipótesis de que Verín contaba con algún tipo de defensa anterior a su abaluartamiento realizado a mediados del siglo XVII.

\section{Fase II: Edad Moderna}

Las construcciones conservadas de esta fase se relacionan con la fortificación abaluartada de la villa y las distintas reconstrucciones de la misma durante el periodo de contienda, identificadas con tres etapas:

\section{Fase lla: en torno al año 1646}

De este momento dataría la construcción de la fortificación, a la cual corresponde el único baluarte conservado en la villa, conocido como el Baluarte de Elle.

\section{Fase IIb: en torno a la segunda mitad del siglo XVII}

Reforma del parapeto de la cara SE, del flanco E y de la cara SW del Baluarte de Elle.

\section{Fase IIc: finales del siglo XVII - siglo XVIII}

Reforma del flanco W y del ángulo formado entre este flanco y la cara SW del baluarte.

Los datos extraídos a través de la lectura de alzados y los sondeos arqueológicos han aportado interesantes conclusiones sobre el sistema constructivo del baluarte y sus posteriores refacciones y reconstrucciones. 

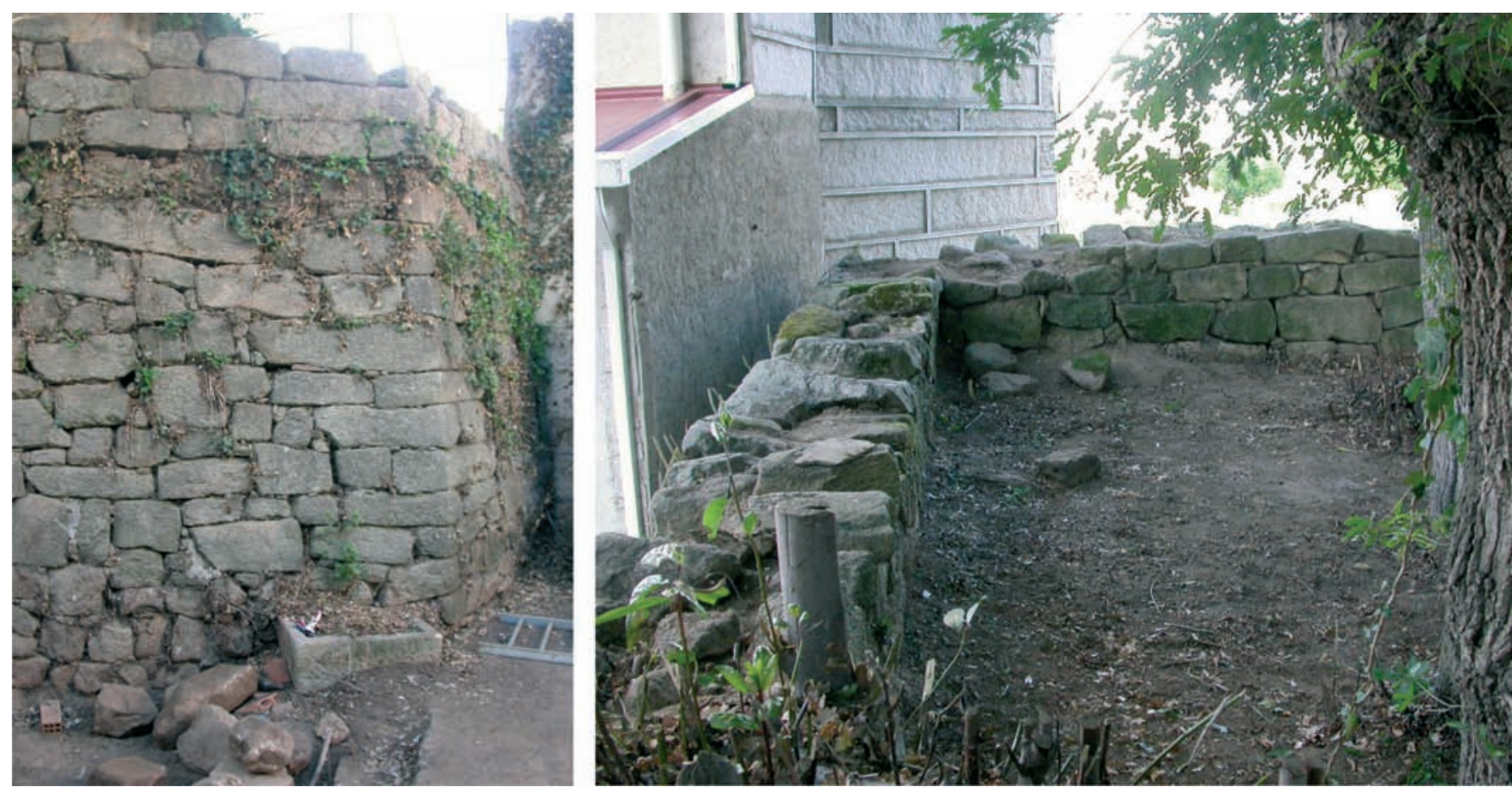

Fig. 9. Distintos aspectos del baluarte de la Calle de Elle. En la imagen de la izquierda la unión entre la cara y el flanco, en la imagen de la derecha la parte superior del ángulo capital

La fase más antigua conservada se localiza en su cara SE y flanco E, aunque el flanco ha sido cortado posteriormente para la construcción, primero, de la casa con patín (en la fase IV) y, después, del alambique (en la fase VII), ya que son las partes del baluarte que menos modificaciones han sufrido a lo largo del tiempo. Se cree que a ello han contribuido dos hechos. Por un lado, esta cara y flanco, son los menos expuestos a las acciones producidas por las riadas, frente a los opuestos que estaban en contacto directo con el río y han sido reconstruidos en varias ocasiones. Por otro lado, del análisis efectuado de todo el proceso de subasta de la fortificación de Verín que tiene lugar entre los años 1836 y $1849^{9}$, se deduce que los vecinos están en contra de esta venta y uno de los motivos que alegan es que las murallas de la fortificación protegen a la villa de las crecidas del Támega, siendo estos mismos vecinos los que en ocasiones se hacen cargo de la reconstrucción de este elemento.

Los informes realizados por el Cuerpo de Ingenieros apoyan esta venta, aunque para el caso de lo que denominan como «murallas del W» los ingenieros están de acuerdo en que contienen las frecuentes crecidas del Támega e incluso proponen la exclusión de estos terrenos

9 1836-1849, Pliego de documentación sobre el proceso de subasta de la Muralla de

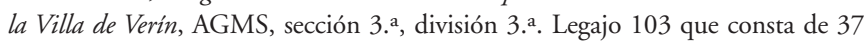
folios.

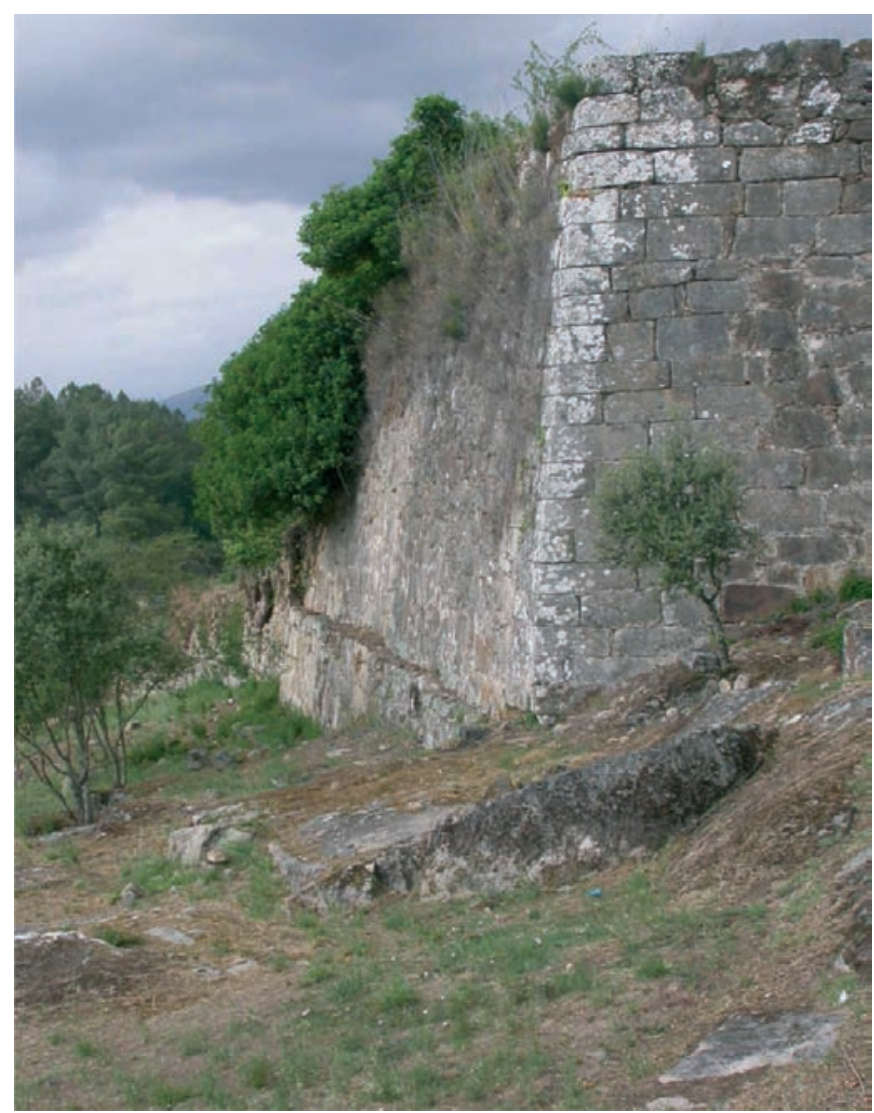

Fig. 10. Baluarte de la fortificación moderna del Castillo de Monterrei. Se puede apreciar que en la cimentación se emplea el mismo sistema de banqueta documentado en el Baluarte de Elle 


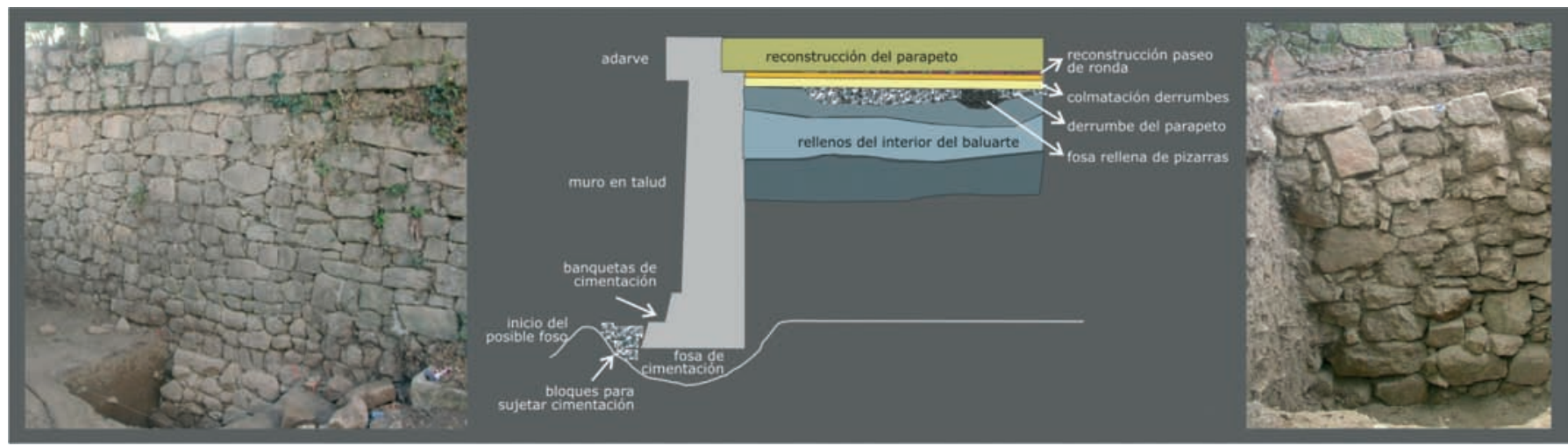

Fig. 11. En la imagen se presenta un croquis de la sección de una de las caras del Baluarte de Elle, en el que se han identificado aquellos depósitos exhumados durante los sondeos arqueológicos. En la imagen izquierda se muestra una fotografía de la parte exterior de la cara del baluarte, en la que se pueden observar el parapeto, la muralla y el sistema de cimentación. En la derecha, la cara interna de la muralla, con el muro que sirve de contención a los terraplenes y de soporte al paseo de ronda

de la subasta. Finalmente, se vende la totalidad de la fortificación a un único licitador ${ }^{10}$ el 8 de mayo de 1849 . Posiblemente la conservación del baluarte venga motivada por su propia ubicación y su relación con la contención de las crecidas del río, además del propio uso de las construcciones realizadas en el solar, destinadas a bodegas. Este tipo de edificaciones necesitan unas condiciones de luz y humedad determinadas que el baluarte proporcionaba con total seguridad.

El sistema constructivo del baluarte documentado en aquellas zonas que se han identificado como originales es el siguiente:

- Cimentación: está constituida por tres elementos: fosa de cimentación, depósito de piedras que colmatan la fosa y doble banqueta que sobresale de la cortina, con un perfil en talud, formando un sistema combinado de banquetas y rellenos que afianzan el terreno húmedo sobre el que se asienta la muralla.

- Caras y flancos del baluarte: al exterior se componen de un muro realizado en mampostería de gran tamaño con tendencia a la regularidad, de 3,10 m de altura, con un perfil en talud. Las esquinas, en ángulo obtuso, están realizadas con grandes bloques de granito, dispuestos a soga y tizón, con la arista biselada. Al interior presenta un aparejo más desconcertado, sin carear, en el que algunos materiales sobresalen del muro. Hacia el ángulo capital el muro se abre dando lugar a una planta curvada, que parece estar reforzando esta zona.

- Adarve: está formado por parapeto, que mide 0,90 $\mathrm{m}$ de altura al exterior y $0,70 \mathrm{~m}$ de altura al interior y su

${ }^{10}$ Este licitador fue don Gregorio Moreno. Con posterioridad a esta venta, estos terrenos pasan a manos de don Pedro Novoa quien, a su vez, en el año 1851 , efectúa una transacción con don Ramón Santa Mariña, nuevo propietario que comienza a edificar dentro de este solar. anchura varía aumentando hacia las puntas del baluarte, siendo la media de $0,90 \mathrm{~m}$; sobresale unos $0,20 \mathrm{~m}$ de la cortina y presenta un perfil recto. Está realizado en mampostería, con bloques fundamentalmente de granito, dispuestos formando hiladas horizontales.

Sobre la parte interior del muro se dispone un paseo de ronda, de unos $0,90 \mathrm{~m}$ de anchura, realizado con bloques de granito dispuestos horizontalmente a modo de losas.

- Terraplenes: interiormente, el baluarte estaba colmatado por una serie de rellenos ${ }^{11}$ compuestos de tierra arenosa y cantos rodados, procedentes del río. La irregularidad en la factura del interior de las caras posiblemente estaría pensada, por un lado, para no ser vista y, por otro, para conseguir un mejor agarre de estos rellenos. La contención de estos terraplenes se efectuaría tanto gracias a la presencia del torreón como por la disminución de su cota hacia el $\mathrm{N}^{12}$.

Poco puede decirse sobre cómo se imbricaría este baluarte con el resto de la fortificación. Hasta el momento se ha localizado únicamente la representación de la villa fortificada en el Mapa de las Minas de Estaño del Valle de Monte $R e y$ del año 1786. En este mapa se dibuja esquemáticamente la fortificación abaluartada de Verín. Sin embargo, gracias a esta representación y a las descripciones posteriores que se conservan, se sabe que la fortificación discurría por el W paralela a la ribera del río. En ese caso, la unión entre

${ }^{11}$ El Baluarte de Elle se corresponde con el tipo baluarte lleno siguiendo la definición de Porras (1995: 53).

${ }^{12}$ En la reconstrucción que se ha realizado de este elemento (ver figuras 6 y 8) no se ha representado este descenso de cota hacia el $\mathrm{N}$, ya que se carece actualmente de la unión que existiría entre los flancos del baluarte y las cortinas de la fortificación. Por ello, se ha decidido cortar los terraplenes a la altura de los elementos que sí se conservan y que, con seguridad, pertenecerían a esta fortificación. 
Fig. 12. Detalle del Mapa de las Minas de Estaño del Valle de Monte Rey (1786), en el cual se aprecian las fortificaciones de Verín y Monterrei

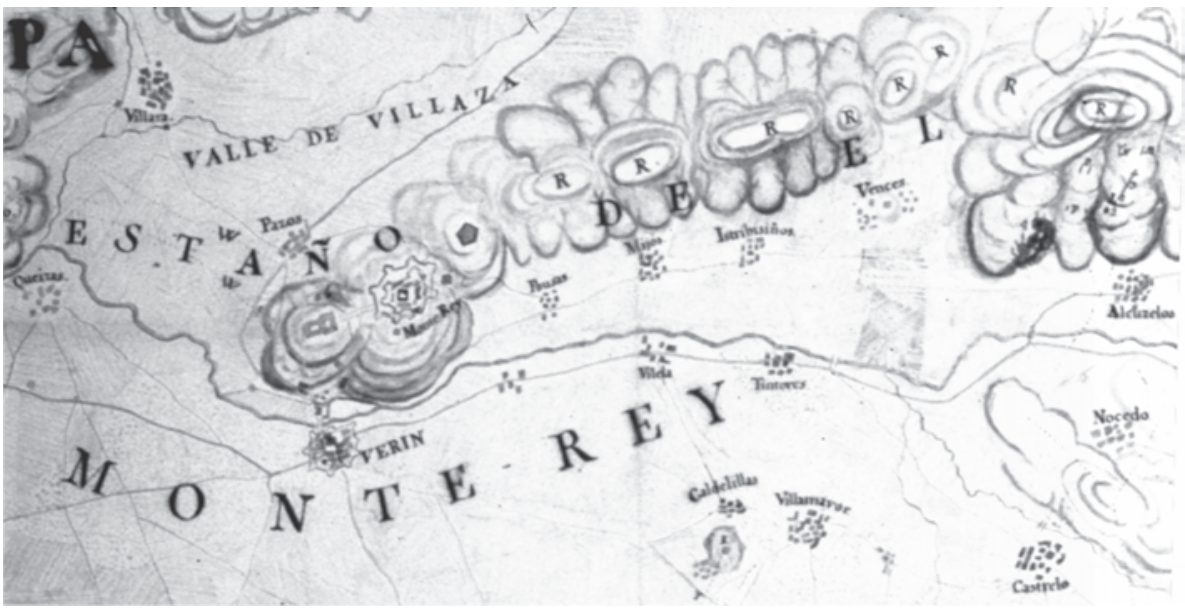

el flanco W y la cortina existente hasta el siguiente baluarte, que según el mapa se localizaría una vez pasado el puente sobre el Támega que une la villa con el Barrio de San Lázaro, no se efectuaría en ángulo, sino siguiendo una línea recta o casi recta ${ }^{13}$. Uno de los aspectos principales de este tipo de fortificaciones era la necesidad de adaptar su planta a la topografía de los lugares en los que se construían y a la existencia de otras defensas anteriores. En este caso posiblemente ambos factores entrarían en juego.

No sucedía lo mismo en la parte E del baluarte, ya que aquí la fortificación se abría hacia el SE. En esta zona se ha localizado mediante fotointerpretación la presencia de un baluarte de mayores dimensiones, por lo tanto, el flanco $\mathrm{E}$ del Baluarte de Elle debía unirse con una cortina que giraba hacia el SE, hasta encontrase con este otro baluarte. Desgraciadamente, en la fotografía aérea más antigua con la que se cuenta se observa cómo esta zona ya estaba construida y se había perdido la presencia de este elemento

Con posterioridad a la construcción del baluarte se documentan una serie de refacciones y reformas en caras y flan $\cos ^{14}$, motivadas por diferentes derrumbes y actividades antrópicas llevadas a cabo sobre el elemento, relacionados tanto con el proceso de la contienda como con las construcciones que posteriormente se realizan en el solar.

Debe tenerse en cuenta, que en el tiempo durante el cual transcurre la Guerra de la Restauración Portuguesa (1640-1668), e incluso con posterioridad a ésta, Verín es uno de los puntos de interés constante en los ataques portugueses, tanto para acceder al Castillo de Monterrei,

\footnotetext{
${ }_{13}$ Respondiendo al tipo baluarte plano, empleado cuando la cortina es demasiado larga y mira al mar o un río, como en este caso, según definición de Sanz Molina (2002).

${ }^{14}$ Los lienzos más afectados son la cara SW y el flanco W.
}

como para entrar desde aquí a otras zonas de la provincia de Ourense. Ello implicaría que la fortificación haya sufrido constantes derrumbes y refacciones, motivadas por las consecuencias directas de las contiendas.

\section{Fase III: 1851}

A esta fase corresponde la construcción en el interior del baluarte de una bodega con antebodega hacia el $\mathrm{N}$, esta fechada en el año 1851. El propietario que emprendió la obra fue Don Ramón Santa Mariña ${ }^{15}$.

La planta trapezoidal de la antebodega, ligeramente girada con respecto a la planta del torreón, podría deberse a la necesidad de buscar «el aire del $\mathrm{N}$ » que se consideraba fundamental para el correcto procesado del vino. Para la construcción de la bodega se reutilizaron parte de los alzados del torreón de la fase I y en la fachada $\mathrm{N}$ se emplearon, a modo de respiraderos, las saeteras que antes tenían un fin defensivo.

\section{Fase IV: en torno al año 1885}

Reforma en el flanco W del Baluarte de Elle y una de las cortinas W de la fortificación de Verín.

\section{Fase V: 1892-1914}

La construcción va adoptando la planta que actualmente se conserva. En un periodo muy corto de tiempo se llevan a cabo varias ampliaciones sobre la bodega de la fase III que van enmascarando los elementos anteriores, sobre todo el torreón.

\footnotetext{
15 Estos datos se han obtenido a través de un documento fechado entre 1851 1855 correspondiente al proceso de litigio entre don Ramón Santa Mariña y doña Estrella Noboa. En él se explican con detalle los cambios de propiedad que sufre a mediados del siglo XIX la finca e incluso las obras que se llevan a cabo en la misma.
} 
En este momento el propietario de la finca es don Gabriel Bazal Romero. Se conserva una relación de los bienes que poseía este señor del año 1892 y en la descripción que se hace en ella de las construcciones del solar se especifica que era de planta baja de $200 \mathrm{~m}$ de extensión, y que lindaría por el $\mathrm{E}$ y $\mathrm{S}$ con la huerta de la finca y el W y $\mathrm{N}$ con las propiedades de doña Estrella y doña María Josefa Novoa. Es decir, en el año 1892 únicamente estaba construida la bodega y antebodega. Esta sería la fecha postquem para esta fase. Para la fecha antequem, se ha empleado el permiso de construcción de la Casa de los Bazales (perteneciente a la fase VI), concedido el 16 de abril de 1914.

Además se concede otro permiso a este mismo propietario en el año 1901 para la reconstrucción del muro de cierre de la finca por el lado del río, que se ha vinculado aquí con la fase $\mathrm{Vb}$.

\section{Fase Va}

Sobre la bodega y antebodega anteriores se construye un segundo piso de planta corrida. Para acceder a la segunda planta se construye un patín abierto, con escalera de dos tramos. Para la construcción de esta escalera se destruye parte del flanco $\mathrm{E}$ del baluarte y se adosa al terraplén que rellena el baluarte. En la fachada exterior $\mathrm{E}$ y $\mathrm{N}$ de la planta alta se dispone un balcón corrido, realizado en madera, del cual se conserva actualmente el que se adosaba a la fachada E. Esta ampliación se destinó a almacenaje.

\section{Fase $\mathrm{Vb}$}

Reforma en la cortina W inmediata al Baluarte de Elle para la apertura de una puerta que comunica el solar con la ribera del río Támega, realizada en un aparejo de sillería de una sola hoja.

\section{Fase Vc}

En esta fase, se amplía un gran espacio de dos plantas hacia el W de mayores dimensiones que lo que existía hasta ese momento, con una planta irregular, alargada, que sigue la misma orientación que el lienzo $\mathrm{W}$ de la muralla en esta zona. Para la construcción de esta bodega se vacía parte del terraplén que se adosaba al flanco W del baluarte.

Se construye también en esta fase la zona correspondiente al espacio bajo cubierta, que cubre los sectores 7, 8 y 10 , con un tejado a dos aguas, a excepción del extremo $\mathrm{N}$ del sector 10 , que se cubriría a un agua.

\section{Fase VI: 1914-1919}

A esta fase corresponde la Casa de los Bazales que cierra el solar por el E, para cuya construcción se concede el permiso a Benigno Gallego Bazal el 16 de abril de 1914. Por los Expedientes de Comprobación del Ministerio de Hacienda se sabe que está finalizada en el año 1919. El edificio cuenta con un doble uso, se destinan a lagares las estancias de la planta baja y a vivienda la planta alta del edificio.

\section{Fase VII: Década de los años 60 del siglo xx}

Se han vinculado a esta fase algunas reformas $y$ ampliaciones llevadas a cabo sobre todo en la fachada E de la construcción, dedicada a explotación vitivinícola, en las que se han empleado los mismos materiales y técnica constructiva.

Por un lado, se cierra el espacio ubicado entre los sectores 8 y 10 , el sector 9 , con muros de sillería de una sola hoja en la planta baja. Éste se destina a almacenaje de botellas de vino y zona de embotellamiento. Sobre esta planta se construye en albañilería un primer piso, equiparando la altura a la del resto de la construcción, quedando cubierta la totalidad de la misma a dos aguas.

Por otro lado, se cierra el patín, resultando ahora un patio interior cubierto a un agua. Se construye también un depósito exterior en sillería regular de una sola hoja, semejante a los depósitos conservados en la planta baja de la Casa de los Bazales.

Por último, se cierra la estancia numerada como sector 5. Como alzado W se están utilizando los restos del flanco E del baluarte, cuyo remate superior se sustituye por un muro de sillería. Posteriormente se practica una apertura en este flanco del baluarte para incluir una lareira y su tiro. La estancia se destina a alambique.

\section{LA VILLA DE VERÍN: UNA FORTIFICACIÓN OLVIDADA}

A medida que avanzaba el proyecto y una vez que teníamos claro que los restos conservados en el solar se correspondían con un baluarte, se consideró que para entender el papel que éste cumplía en el sistema defensivo de la villa, sería necesario entender cómo había sido su fortificación en época moderna. Por ello, nos planteamos una estrategia de trabajo en la que se combinaron varias metodologías con la intención de maximizar la información disponible sobre esta época.

La actual configuración urbana de Verín no dejaba entrever la preexistencia de una fortificación. Los escasos restos que de ella quedaban estaban ocultos en el interior de un solar bajo construcciones de distinto tipo. Únicamente las calles Muralla y Foso suponían una vinculación directa a este elemento, y algunos vecinos todavía recordaban el topónimo Puertas de Madrid que 
Fig. 13. Estructuras identificadas durante la prospección del casco urbano de Verín. En la imagen superior izquierda el muro con saetera ES050530U04; en la inferior derecha el muro en talud ES050615U01; las otras dos imágenes se corresponden con muros localizados en la Calle Muralla
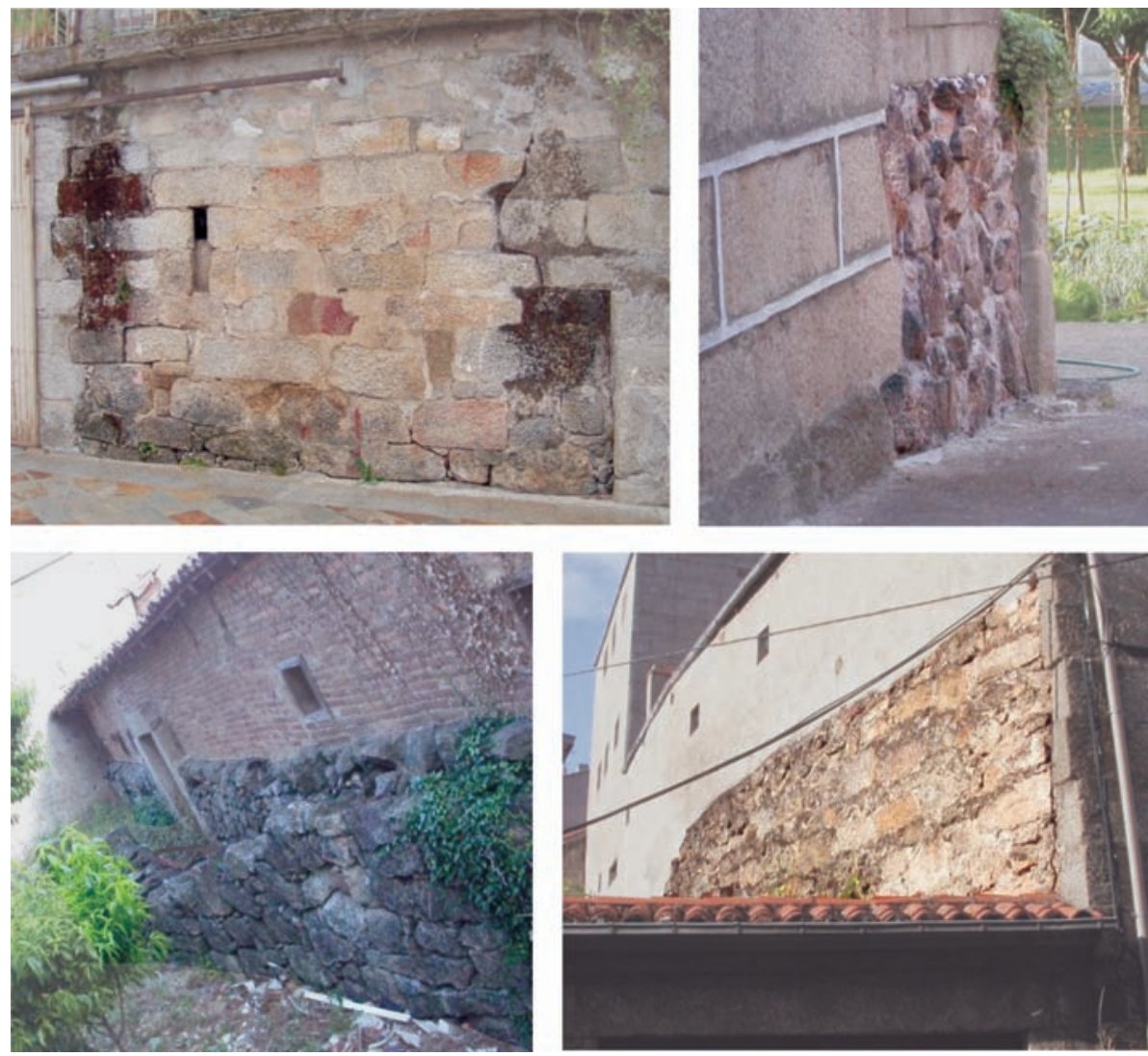

hacía referencia a la ubicación en la que éstas se encontraban ${ }^{16}$. Es decir, se había eliminado de la memoria el papel que la villa había jugado como fortificación de frontera. Únicamente algunos estudiosos y vecinos comprometidos ${ }^{17}$ habían conservado a través de sus escritos algunas referencias a la misma.

Como ya se indicó, la prospección del casco histórico se completó con la fotointerpretación de fotografías aéreas e imágenes satélite. El motivo fundamental de complementar ambas técnicas de análisis era que las características de los espacios susceptibles de ser analizados a través de la prospección con el fin de identificar el trazado de la fortificación de Verín, eran extremadamente complejas en la actualidad, por lo que se hacía necesario acudir a este segundo tipo de análisis, ya que la fotografía aérea podría aportar información inédita que añadir al estudio de la misma.

En el caso de la aplicación de la fotointerpretación arqueológica al estudio de un espacio urbano, debe tenerse

${ }^{16}$ La puerta había sido eliminada con posterioridad a 1849.

${ }_{17}$ Queremos mostrar nuestro agradecimiento a aquellos vecinos de la villa de Verín que amablemente nos ayudaron, nos proporcionaron información o nos permitieron consultar sus archivos particulares durante el transcurso de estos trabajos, sobre todo a D. Alberto Vega y muy especialmente a D. Eduardo Castro. en cuenta que las variaciones sufridas en los últimos cincuenta años han afectado sobremanera a los restos materiales que conformaron las ciudades y pueblos en el pasado, de esta manera, se hace muy complicado identificar las estructuras que formaron parte de su evolución histórica utilizando únicamente las imágenes actuales de los mismos.

En el estudio de Verín se revisaron imágenes tomadas en diferentes momentos para conocer cómo había sido su evolución urbanística reciente y para poder delimitar el recorrido de la fortificación que aparecía mencionada en la documentación de distintas épocas.

Al tratarse de un entorno urbano, la necesidad principal era que las imágenes contasen con la suficiente nitidez, pero las fotografías del Vuelo Americano carecen de ella, impidiendo determinar con seguridad la forma exacta de cada uno de los objetos que componen el contexto de estudio. En este análisis se intentaron identificar aquellos indicios físicos que pudieran suponer el reconocimiento material del trazado de la fortificación en la trama urbana, así como las variaciones en el trazado urbano que ayudasen a comprender la evolución de la villa desde la mitad de siglo XX hasta nuestros días.

En este estudio se tuvieron en cuenta el tamaño de los 

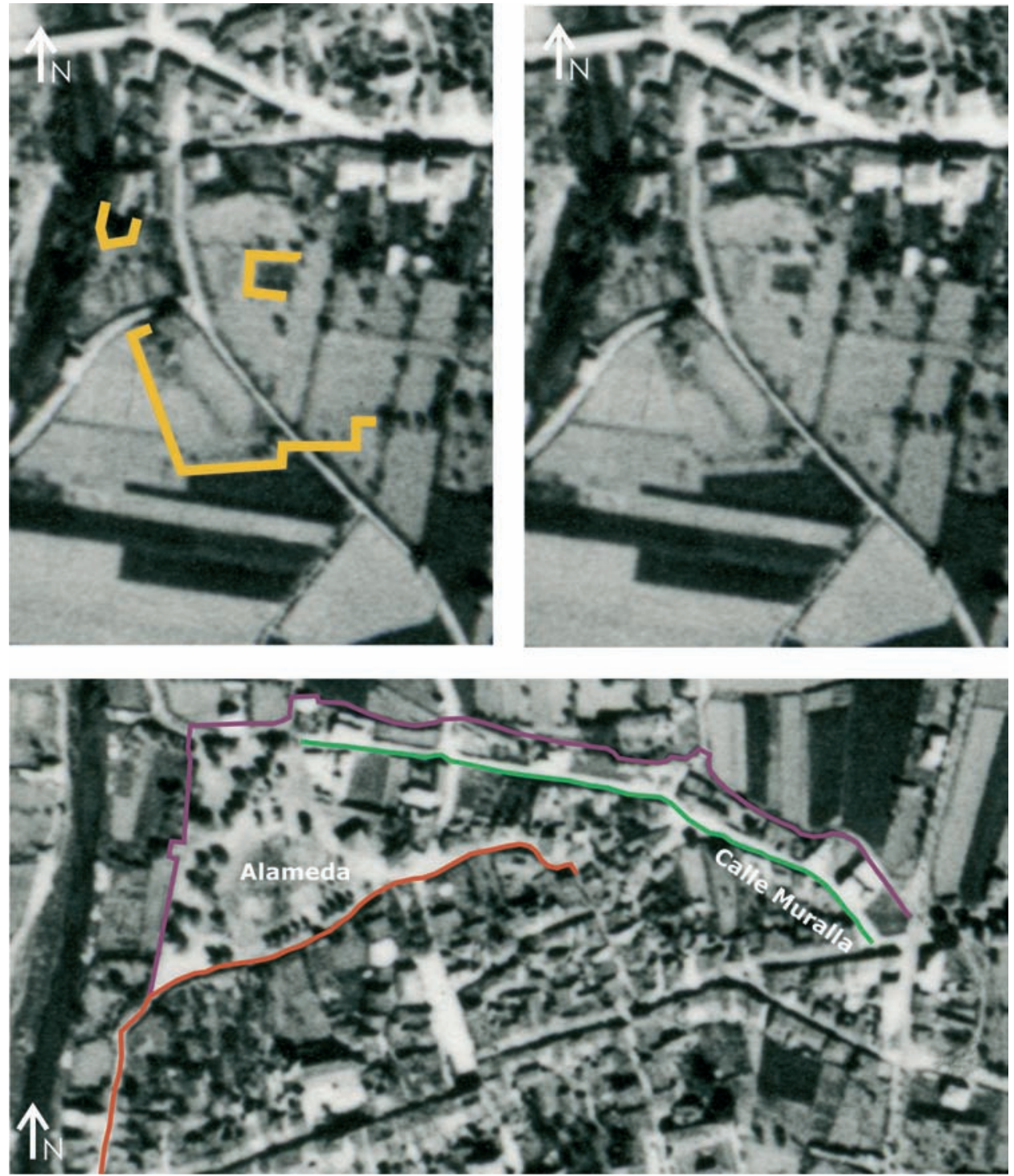

Fig. 14. Resultados de la fotointerpretación de la fotografía aérea de 1957. Arriba posibles estructuras localizadas al S-SE del Baluarte de Elle; abajo el trazado de varias líneas de muralla que delimitarían Verín hacia el $\mathrm{N}$

objetos, la forma, las sombras, el tono, textura y la distribución de los elementos; no así las variaciones de escala en los diferentes puntos de cada una de los fotogramas, ya que el fin último del análisis no era llegar a obtener medidas exactas de estructuras, sino la identificación de las mismas.

Por otra parte, se utilizaron las imágenes satélite más contemporáneas para situar en ellas las estructuras y variaciones urbanísticas localizadas en las imágenes más antiguas, de forma que la ubicación en el espacio concreto que ocupaban fuera reconocible con mayor facilidad. Con ello, se ha pretendido determinar dónde y cómo ha variado la villa para poder llegar al por qué de estas variaciones y, finalmente, determinar si en ellas ha tenido o no que ver el trazado de la muralla.

Finalmente, los resultados de la prospección y la fotointerpretación, fueron comparados con la representa- ción de la fortificación documentada en el Mapa de las Minas de Estaño de 1786, que aunque no reproducía con precisión la planimetría de la villa, sí se observa la configuración urbanística de Verín enmarcada dentro del trazado de una muralla abaluartada, las principales vías de comunicación que parten de la villa y la conexión con el Barrio de San Lázaro. Todos estos elementos fueron digitalizados y superpuestos sobre una fotografía satélite de Verín, para posteriormente compararlos con los documentados a través de los análisis arriba mencionados.

La prospección arquitectónica del casco urbano proporcionó escasas evidencias materiales del trazado de la fortificación, correspondiéndose, por otro lado, a dos periodos cronológicos distintos.

Además de los restos que se localizan en el interior del solar, muy próximo a éste y volcado también al río 
Támega, se emplaza un muro realizado en un aparejo de sillería irregular de granito en el que se conserva una saetera, abocinada al interior (ES050530U04). Teniendo su localización, su relación y proximidad con los restos del torreón ubicado en el solar objeto de estudio y la tipología de la saetera, podría tratarse de los restos de una construcción anterior, tal vez de otra torre cuya finalidad sería la defensa de un paso sobre el río Támega. De ser así, ambos torreones podrían funcionar de forma conjunta, protegiendo este paso, lo cual apoyaría la hipótesis que plantean algunos autores de que el puente se encontraba anteriormente más hacia el $S^{18}$.

En la calle Mariano Carrero, próxima a las Puertas de Madrid, se localiza un muro (ES050615U01) realizado en un aparejo de mampostería que se reutiliza en la construcción de una casa. Este muro sigue el trazado de la muralla de época moderna y, como ésta, tiene un perfil en talud, por lo que se ha incluido como parte de los restos de la muralla.

Ambos elementos, conjuntamente con el torreón y baluarte de la calle de Elle, son los únicos que con seguridad se pueden identificar como partes de la distintas cercas de la villa, dos de época bajomedieval y dos del siglo XVII.

Por otra parte, se han localizado otros dos elementos reutilizados en sendas construcciones de la calle Muralla (ver figura 13) que podrían estar relacionados también con la fortificación moderna. Ambos seguirían el trazado de la muralla y han sido reutilizados en construcciones contemporáneas. El segundo de ellos se reutiliza en la construcción de una fábrica. Se divide en dos muros, el interior incluye las jambas de una puerta y el exterior va abriendo en ángulo. En esta zona, tanto la planimetría de 1786 como la fotointerpretación de la foto aérea de 1957 muestran un quiebro en la muralla. En todo caso, no parece tratarse de un baluarte sino de una figura triangular, a modo de revellín, protegiendo una posible puerta.

En cuanto a los resultados de la fotointerpretación, los elementos más relevantes son aquéllos que pudieran tener que ver con la fortificación de la villa. En la fotografía aérea de 1957 se observa con una tonalidad más clara una línea quebrada delimitando lo que pudo ser otro de los baluartes que circundaban por el S la población (ver figura 14). En esta zona las fincas no siguen un ritmo regular en su planta. Normalmente, en Verín la delimitación de las propiedades suele estar basada en divisiones paralelas y

${ }^{18} \mathrm{El}$ actual puente se reforma en el año 1795, según apuntan algunos autores (Madoz, 1849; Carreras Candi, 1980: 736). transversales a la forma que delimita el polígono al que éstas pertenecen. En este caso, llama la atención la forma irregular que adoptan las fincas que quedan envueltas por los posibles restos de un baluarte.

Si comparamos esta imagen y la información revertida de la planta del Mapa de las Minas de Estaño, este baluarte estaría marcando ese trazado circular que ampliaría el espacio urbano hacia el $S$ de la actual calle Luis Espada (ver figuras 12 y 14), según se observa en el mapa. Esta muralla abaluartada estaba circunscribiendo un espacio añadido a la configuración urbana de la villa hacia el $\mathrm{S}$ del casco antiguo. De tal manera, este baluarte estaría en conexión con el de Elle y quizá con otro situado en la confluencia de las actual calle del Elle con la Avenida de Portugal, lugar éste que, tanto en las imágenes de 1957 como en las actuales, aparece con una planta apuntada en la formación de la manzana situada entre aquellas vías. Esta delimitación de caminos parece estar contorneando el espacio que pudo haber estado ocupado por otro de los mencionados baluartes.

En la zona $\mathrm{N}$ de la villa, unido a la propia toponimia que hoy se mantiene con fuertes referentes a este elemento, como son las calles Muralla y del Foso, también se conserva una configuración que podría estar continuando la traza de diferentes cercas o murallas que, como en el caso de la zona sur, habrían ido ampliando el espacio urbano en esta franja.

En este caso, en las imágenes de 1957 se localiza la cerca que ya en ese momento era utilizada para la delimitación de las parcelas y que correspondería con el trazado de la calle del Foso. Si observamos lo que ocurre en el resto de los terrenos agrarios más cercanos a la villa, veremos que no es habitual el hecho de construir grandes muros que delimiten las propiedades y es solamente en este contexto donde encontramos esos cercados siguiendo un trazado longitudinal, pasando de una propiedad a otra y no cerrando éstas en los demás frentes. Por otra parte, se observa cómo la línea trazada hace ligeros quiebros en aquellos puntos desde los que parten los caminos (ver figura 14), hecho que podría estar relacionado con la existencia de algunos elementos para la protección de las entradas, como se comentó en el caso de los restos conservados en la calle Muralla. Podría ser ésta entonces la traza de la muralla más reciente en el tiempo, posiblemente correspondiente a las obras exteriores que circundarían la Plaza Fuerte cuyo trazado en esta época estaría reutilizando y ampliando el espacio urbano medieval, que fue repuesta, reparada y reutilizada para el cierre de las propiedades hasta la segunda mitad del siglo XX. 


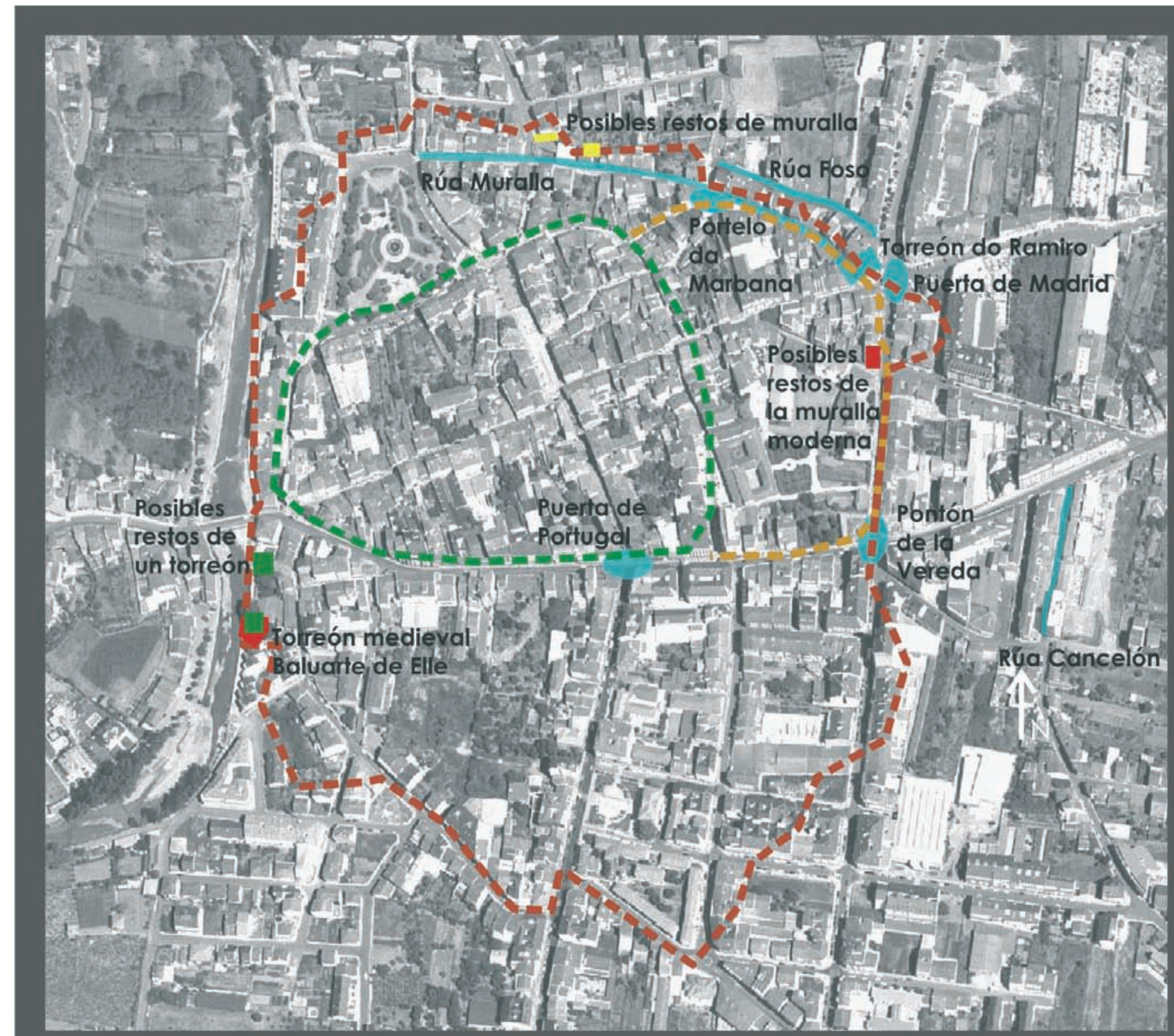

\section{$=\mathbf{n =}$. Posible ampliación de la cerca medieval \\ Delimitación de la muralla moderna \\ Toponimia relacionada con la muralla \\ Estructuras medievales \\ Estructuras relacionadas con \\ la fortificación moderna \\ Estructuras dudosas de la fortificación moderna}

Fig. 15. Síntesis de los trabajos realizados en el casco urbano de Verín, con la reconstrucción hipotética de los trazados medieval y moderno

A su vez, esa muralla pudo estar reaprovechando en el frente W, el que vierte hacia el Río Támega, el trazado de otra anterior, el cual abarcaría un espacio menor intramu- rallas y podría corresponderse con la planta de un primer asentamiento delimitado o cercado. En esta primera cerca no se incluiría el terreno ocupado por la Alameda, el cual 
quedaría incluido en la segunda cerca con el topónimo Alameda de Adentro ${ }^{19}$.

Una de las dificultades de este estudio fue el no haber podido, en la mayor parte de los casos, contrarrestar in situ las referencias tomadas de la lectura estereoscópica de las fotografías, ya que en la actualidad es muy difícil saber si perduran restos de posibles cercas o murallas en este contexto mediante simple observación visual sin acceder a las propiedades particulares y sin tener capacidad para la recopilación de otros datos, con la excepción de los casos comentados anteriormente.

Lo mismo sucede con aquellas informaciones que hacen referencia a diferentes estructuras relacionadas con la muralla que no ha sido posible identificar en las imágenes fotográficas, es el caso de la localización de las posibles puertas que desde la muralla darían acceso a los terrenos del Convento de la Merced o de los topónimos relacionados con puertas, portillos o accesos, recogidos en el Catastro de Ensenada, ya que la visibilidad de estas estructuras dentro del entramado urbano ha pasado totalmente desapercibida, si es que en 1957 todavía se mantenía alguno de estos elementos.

Por todo lo que se ha venido comentando en los párrafos anteriores, que incide sobre todo en la dificultad de identificar determinados elementos en el urbanismo actual de Verín que pudieran tener relación con su fortificación en épocas anteriores, creemos que debemos ser bastante cautelosos a la hora de establecer la delimitación de la fortificación moderna y plantear únicamente por el momento una reconstrucción hipotética de su trazado (figura 15) que habrá que verificar a través de otro tipo de actuaciones arqueológicas, como la intervención en el subsuelo.

\section{VERÍN-MONTERREI: LA FORTIFICACIÓN DE UNA VÍA DE TRÁNSITO}

Para entender la historia de Verín y su fortificación en época moderna, con motivo de la Guerra de la Restauración Portuguesa, debemos encuadrarla en un contexto territorial más amplio y en el papel que jugó en el desarrollo de la guerra en esta zona de la frontera. La historia de la villa está directamente vinculada a la del Castillo de Monterrei. Aunque sus orígenes son confusos, algunos autores los sitúan en época romana, vinculados a las fases de romanización del castro de Baroncelli ${ }^{20}$, empla-

\footnotetext{
19 Este topónimo está tomado del Catastro de Ensenada.

20 «Et usque cessavimus ad archa quam invenimus arrigata iuxta domus Ansemondo prope rivulo Tamara, et ipsa archa in directo ad castrum Baroncelli, qui dividet Inter. Villam sancto Felice [Pazos] et villam Sancta Maria [Verín]» (Andrade et alii, 1995: 146-148), documento fechado en el año 950.
}

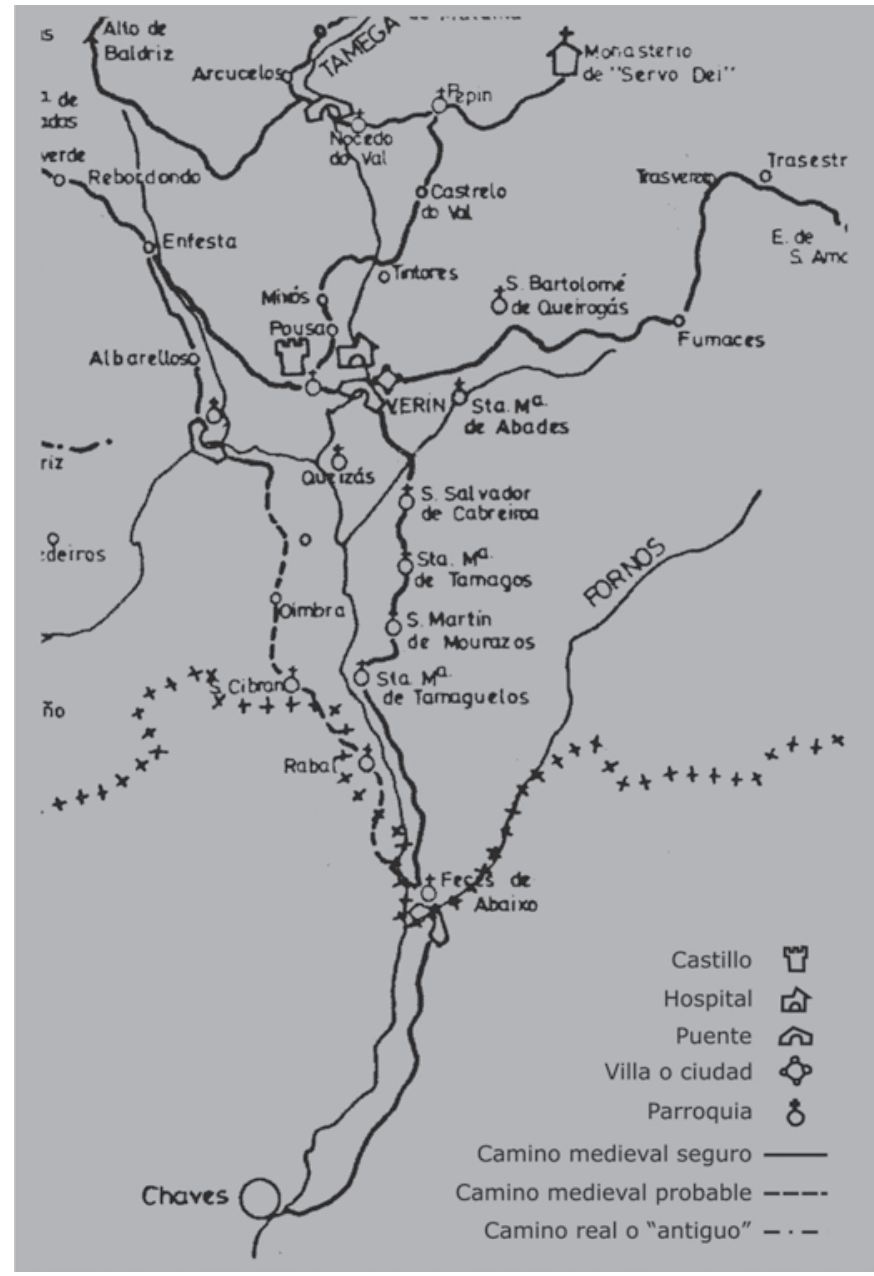

Fig. 16. Caminos medievales de Verín y su entorno, extraído del mapa de los caminos medievales de la provincia de Ourense de Elisa Ferreira (1988)

zado en el actual Castillo de Monterrei, a $1 \mathrm{Km}$ al NW de Verín.

De la ocupación de esta zona en época romana da constancia Taboada a través de la referencia a una vía romana secundaria y la inscripción honorífica del puente de Chaves: «Bordeando la eminencia [Monterrei] pasaba una vía secundaria que unía los Itinerarios 17 y 18 de Antonino Pío discurriendo paralela al río epónimo de las tribus tameganas que colaboraron en la construcción del puente de Chaves» (TABOADA ChIVITE, 1947: 3).

La primera referencia documental a Verín se realiza en una escritura del año 931 mediante la cual «Pedro y su mujer Villone cambian a Velasco Rodríguez y su mujer Trudili la vila de Verin, junto al río Támega, por la de San Pedro de Camesella» (GARCía Álvarez, 1964: 358, 366-367).

Posteriormente, pasará a pertenecer al Monasterio de Celanova. La primera referencia de esta pertenencia es del año 1026 según se recoge en el «Inventario de homines de 

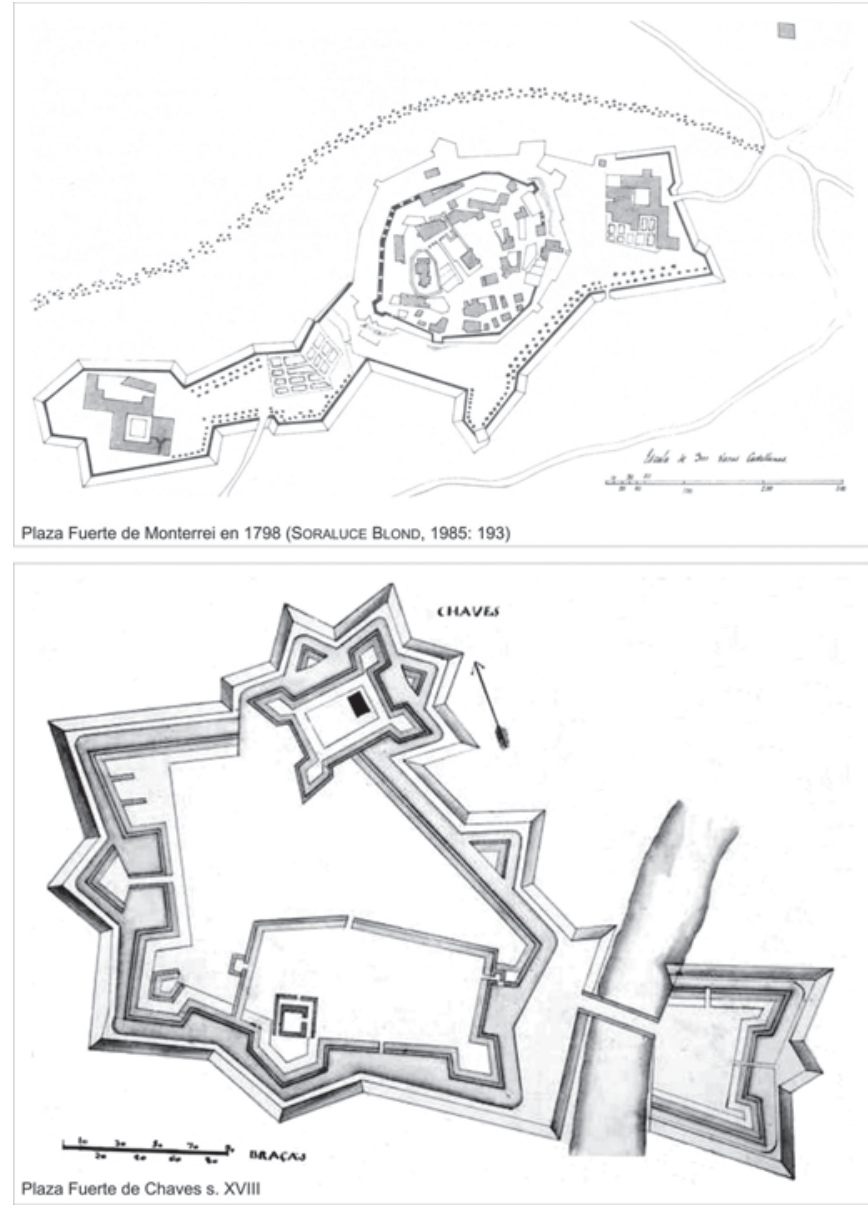

Fig. 17. Planimetría de las Plazas Fuertes de Monterrei y Chaves en el s. XVII, puntos estratégicos en esta zona de la frontera

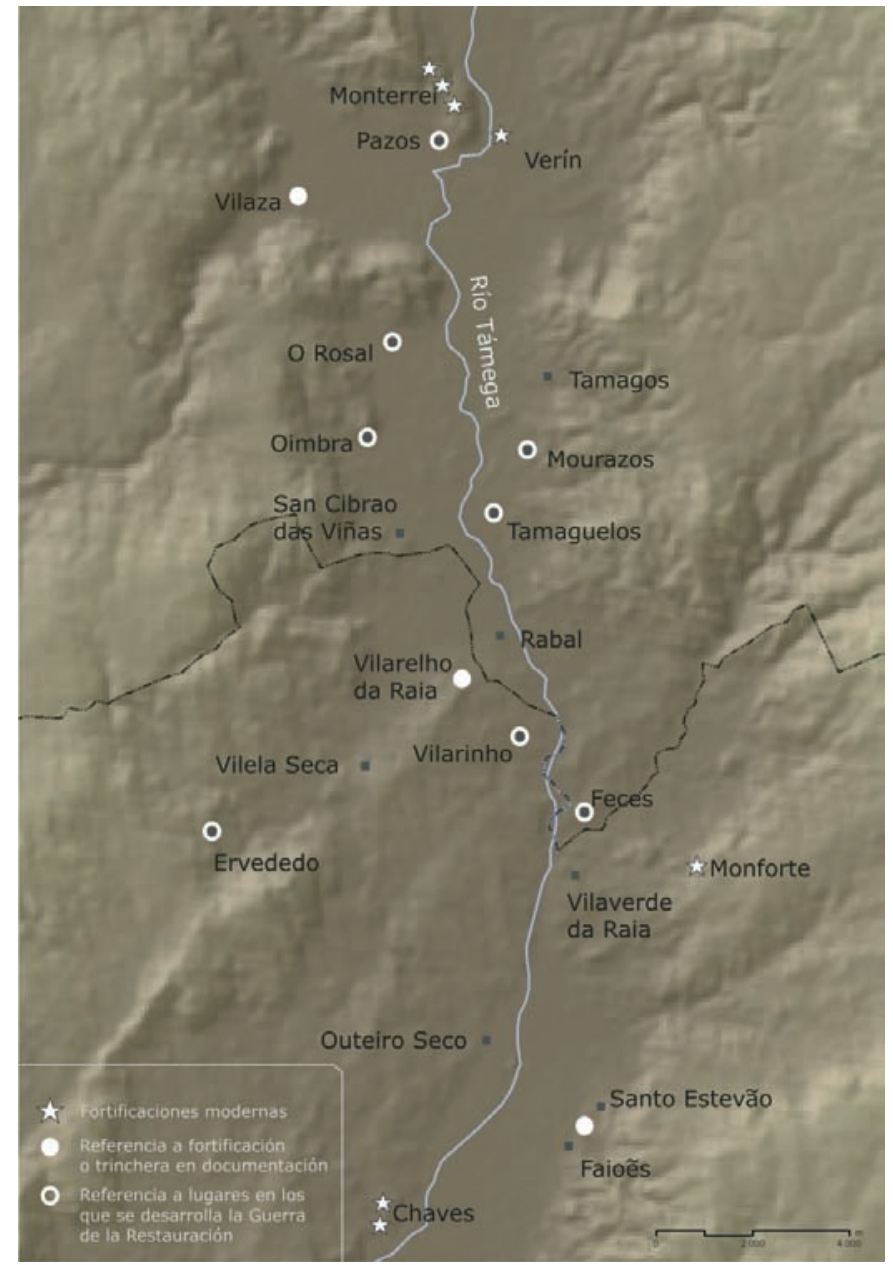

Fig. 18. Mapa con las principales poblaciones localizadas entre Chaves y Monterrei. En él se han identificado las fortificaciones modernas conservadas, aquéllas a las que se hace referencia en la documentación histórica o bibliográfica, así como los lugares mencionados en las crónicas de la Guerra de la Restauración Portuguesa en los que tiene lugar algún episodio de la misma

que señalar el denominado Camino del Sudeste, que se dirigía hacia Santiago desde el Sur y centro de la Península, siguiendo la Vía de la Plata y entrando en Galicia por tierras orensanas. Este es un camino que se mantiene activo durante la Alta Edad Media.

Se convierte Verín, en este periodo, en un importante enclave en el que se produce el cruce de varios caminos relacionados con un fenómeno de gran importancia desde el punto de vista religioso, social, político y económico. Debe recordarse la descripción que hacía el Licenciado Molina sobre esta zona, en la que se hace alusión a este mismo fenómeno, además de a la riqueza del valle en el que se emplaza la villa ${ }^{22}$. Por otro lado, Elisa Ferreira hace

22 «El otro río que nace en aquella tierra se llama Tamais (Támega), va por unas montañas ásperas y estériles, más se restaura rápidamente, porque hay luego uno de los más frescos valles y vistas que hay en Galicia que es el valle de Monterrei, y atravesándolo de cabo a cabo, tiene este valle tres leguas de largo y una de 
referencia a la existencia de tres caminos que se entrecruzan en Verín en época medieval, alguno de los cuales se documenta ya en el año 950. Apunta también que ya a finales del s. XIII existía un puente sobre el río Támega a la altura de la villa de Verín ${ }^{23}$.

Además de tratarse de una zona de paso, también era Verín un lugar de parada relacionado directamente con la hospitalidad y peregrinación, ya que, uno de los principales hospitales de peregrinos de la provincia, conjuntamente con los de Monterrei, Xunqueira de Ambía, Allariz y Ourense, se localizaba en esta villa, aunque se desconoce de qué fecha sería la fundación del hospital de Verín.

Sigue Verín en poder del Monasterio de Celanova hasta que en el año 1555 es desmembrado por el rey Carlos I (TABOADA Chivite, 1947: 5). Ese mismo año, estos lugares son vendidos al Conde de Monterrei (TABOADA Chivite, 1949: 64).

Contaba en estas fechas Verín con 300 vecinos, cuyo crecimiento demográfico se había beneficiado del despoblamiento paulatino que venía sufriendo Monterrei desde comienzos del s. XVI (TABOADA CHIVITE, 1949: 63).

La primera referencia documental sobre la existencia de una fortificación o amurallamiento de la villa de Verín data del año 1644 en el que Felipe IV solicita una relación de las necesidades defensivas de la frontera, de la cual se encarga el ingeniero Juan de Villarroel y Prado para la zona de Monterrei. Su cometido es estudiar el abaluar-tamiento de la fortaleza de Monterrei y la villa de Verín. De este informe se desprende que tanto la plaza de Monterrei como los "puestos de Berin»" ${ }^{24}$ deben repararse. Se aceptó y emprendió, entre otras obras, el atrincheramiento de Verín. Al año siguiente el Marqués de Aytona, Capitán General de Galicia, afirma que "Berín era una trinchera sola de mala calidad sin estacada» (RODRíGUEZVILLASANTE, 1984: 192), por lo tanto, cabe pensar que probablemente aún no hubieran empezado las obras para transformar Verín en una fortificación a la moderna en este momento.

A mediados del s. XVII existía entonces una villa cuyo perímetro estaría atrincherado, pero no abaluartado, que servía como apoyo logístico a la fortaleza de Monterrei, un apoyo en el acceso a la misma desde el valle del Támega, en

ancho, es de los más abundantes que hay en el reino y en toda Castilla, tiene de cuantas cosas en general se pueden pedir con gran sobra de pan y vino y ganado, todo género de caza y toda suerte de frutas valiosas y abundantes [...] para este río al pie de una cuesta junto a un lugar que se dice Verín que es lugar de gran paso [...]» (Licenciado Molina, 2003: 157).

23 «[...] y entraba en la villa de Verín. Cruzando un puente sobre el Támega que a fines del s. XIII ya recibía mandas en los testamentos [...]» (Ferreira, 1988: 176).

${ }^{24}$ Rodríguez-Villasante, 1984: 192. una zona que suponía un cruce de caminos desde Portugal, Castilla y otras zonas de Galicia.

En el relato que lleva a cabo Fernández Alonso sobre la Guerra Hispano-Lusitana, las menciones que hace a Verín, siempre se vinculan a la fortificación de Monterrei: «La villa de Chaves, plaza fronteriza del vecino reino, hallábase asimismo ocupada por los escuadrones portugueses, dispuestos á invadir de un momento á otro las llanuras de Verín, para asaltar el castillo de Monterrey» (FERNÁNDEZ AlONSO, 1893: 10).

Fernández Alonso fue cronista de la provincia de Ourense. Su relato narra los hechos acaecidos en la misma entre los años 1640 y $1713^{25}$, relacionados con las guerras mantenidas entre España y Portugal. Cabe destacar de la Guerra Hispano-Lusitana algunos aspectos que son de interés para el presente trabajo: por un lado, las constantes referencias a la villa de Verín y la plaza de Monterrei, ya que eran ambos puntos frecuentemente amenazados por las tropas portuguesas que, generalmente acuarteladas en la plaza de Chaves, planeaban desde aquí la toma de la llanuras de Verín para luego apoderarse de la fortaleza de Monterrei, uno de los principales bastiones fronterizos de la provincia. Por este motivo, desde los ejércitos gallegos se mandaban constantemente tropas que desde aquí defendieran esta zona de la raya. Ello implicaba la necesidad de contar con almacenes y cuarteles en los que alojar a las tropas, además de tener que proporcionar armas y avituallamiento a los soldados. Suponía también, el reclutamiento constante de paisanos ${ }^{26}$ y la continua recaudación de tributos como así lo atestigua Fernández (1893: 72-3).

Teniendo en cuenta la dilatada duración de la guerra y los estragos generados por la misma, poco a poco se iban mermando las provisiones, hundiendo la economía, descendiendo la demografía y, consecuentemente, decayendo el ánimo de las gentes. Por otro lado, era necesaria una constante reparación de las fortificaciones de ambas villas, como así se manifiesta en numerosos puntos a lo largo del texto de Fernández.

En torno a 1644-1646 se decide reforzar las defensas de Verín siguiendo los planteamientos de la fortificación abaluartada, como así lo demuestran el baluarte de Elle o el Mapa de las minas de Estaño. Por otro lado, en la inscripción reutilizada en el baluarte de la calle de Elle aparece la fecha de 1646. Hasta este momento, es probable que la fortificación de la villa, por una parte, reutilizase elementos conservados de algún sistema anterior $\mathrm{y}$, por otra, se

\footnotetext{
25 Última fecha a la que hace referencia el autor.

${ }^{26}$ Que debían abandonar sus trabajos cotidianos desatendiendo así la propia economía de sus casas y haciendas.
} 

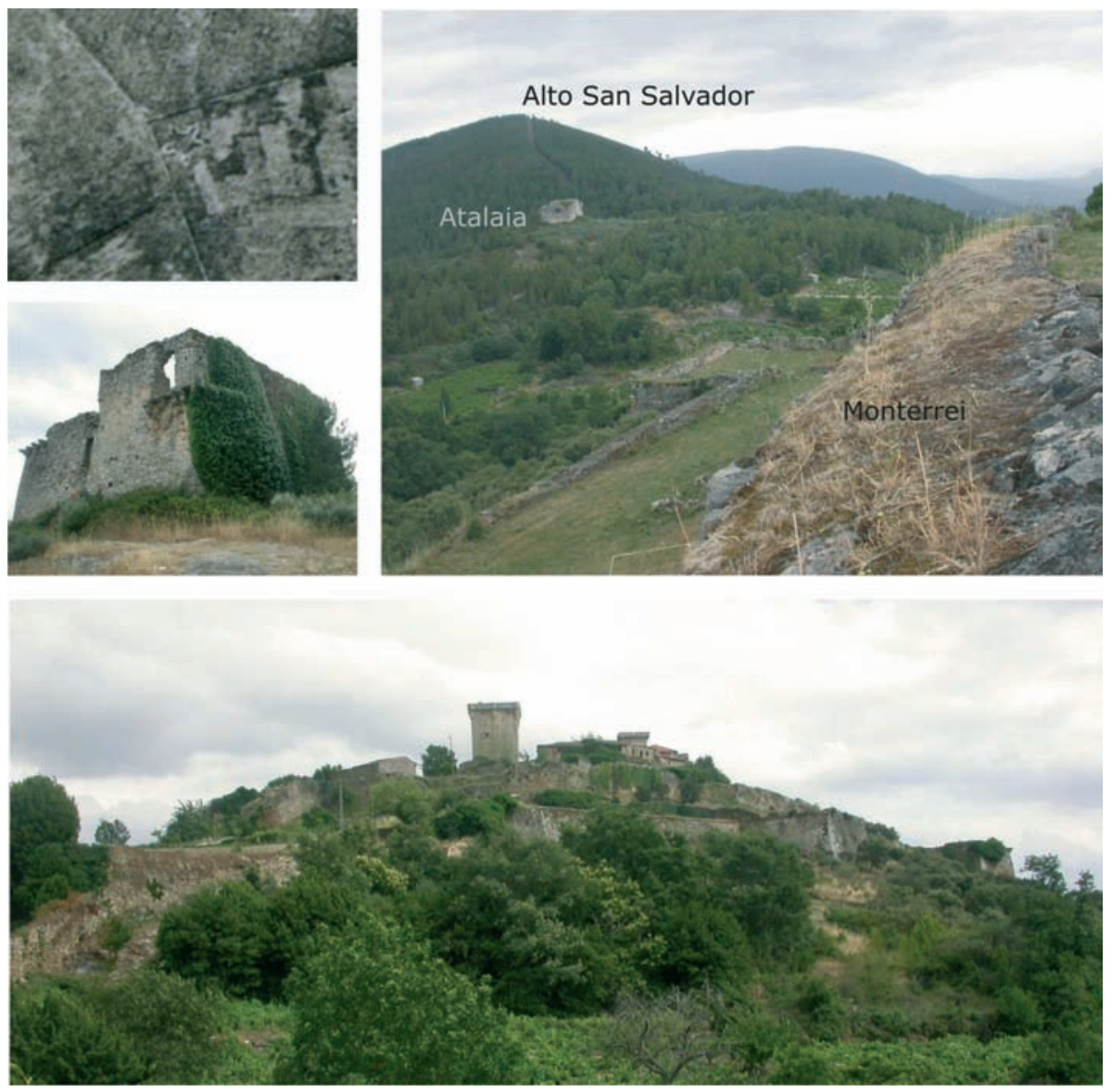

Fig. 19. Fortificaciones localizadas entre Monterrei y el Alto de San Salvador

compusiese de trincheras que podrían corresponder a la fortificación de campaña que se habría ido construyendo a medida que avanzaba la Guerra de la Restauración Portuguesa.

Sin embargo, aunque en este momento pudiera iniciarse la construcción del abaluartamiento, no debió concluirse o se consideró insuficiente, ya que se documentan noticias en fechas posteriores en las que se sigue haciendo referencia a la necesidad de fortificar la villa. Cabe pensar que resultaría difícil proyectar una fortificación adecuada para ambas poblaciones en tiempos de guerra $y$, sobre todo, llevarla a cabo.

De todo ello se desprende que la fortificación de Verín fue creciendo, consolidándose y reparándose de forma constante con el propio discurrir de la guerra. En todo caso, en algún momento situado entre mediados del s. XVII y principios del XVIII Verín queda completamente abaluartado.

Las principales plazas fuertes localizadas en esta zona de la frontera son Chaves, en la parte portuguesa, y Monterrei, en la gallega. Ambas se rodean de una serie de fortificaciones que protegen la entrada a las plazas fuertes.
Para el caso gallego, Verín formaría parte de un complejo sistema en el que la principal fortificación la constituye Monterrei. En su entorno inmediato se fortifican otros enclaves destinados a proteger puntos concretos del castillo o del acceso al mismo. Verín, en el valle defendiendo el acceso a Monterrei desde Portugal. La Atalaia, situada a unos $420 \mathrm{~m}$ al NNW del castillo, desde la cual se defendería el flanco más débil de la plaza y la fuente de agua potable, además de orientarse hacia la entrada al valle desde Portugal. Esta construcción de planta cuadrangular comienza a construirse en 1640 y se remata en 1664 (DASAIRAS VALSA, 2008: 19).

$\mathrm{Y}$, a $1.600 \mathrm{~m}$ al NNW de Monterrei, en el Alto de San Salvador, un fuerte de planta estrellada de cinco baluartes. Según Dasairas (2008: 19), este fuerte se proyectó pero nunca llegó a construirse, sin embargo éste se ha documentado gracias a la fotointerpretación y, todavía hoy, pueden verse los restos del mismo, que únicamente conserva un baluarte completo y la mitad de otro. En la fotografía aérea del año 1957 (ver figura 19) se aprecia la planta estrellada. 


\section{CONCLUSIONES}

Cuando se iniciaron los trabajos arqueológicos en el solar n. ${ }^{\circ} 14$ de la calle de Elle, dos eran las preguntas de partida a las que se debía intentar responder a través de los resultados que se obtuviesen de los mismos.

Una, de carácter patrimonial e histórico, era si los muros que se localizaban en el interior de este solar pertenecían o no a un baluarte. Otra, de carácter fundamentalmente práctico y actual, era si el proyecto arquitectónico planteado en el interior de este solar era viable.

Llegados a este punto, podemos afirmar que en el solar no sólo se conserva un baluarte, sino también los restos de un torreón, ambos reflejo de dos sistemas defensivos que responden a planteamientos totalmente distintos y que, a su vez, son unos de los escasos restos materiales que se mantienen en pie de la fortificación de Verín.

Además de lo que la conservación de ambos restos supone patrimonialmente para la villa, cuyo crecimiento urbanístico ha ido ocultado su memoria histórica, conlleva la apertura de una nueva hipótesis sobre su organización espacial y defensiva anterior a su abaluartamiento en el s. XVII y confirma la existencia de un sistema defensivo fechado en época moderna.

$\mathrm{Si}$ analizamos qué elementos de los estudiados nos llevan a afirmar la existencia en Verín de un sistema defensivo en época medieval, estos aunque escasos son significativos: un torreón, parte del alzado de otro torreón, dos topónimos que aluden a esta figura y una referencia escrita. Si ponemos en relación la ubicación de estos elementos, la conservación de dos ejes principales de la villa (NNW-SSE y NE-SW) en su urbanismo actual y la forma almendrada de lo que parece su recinto urbano primigenio con la planta ligeramente circular de su posterior abaluartamiento, podríamos llegar a la conclusión de que la forma de su planta abaluartada respondió no sólo a la propia topografía de la villa, sino también a la persistencia de otros elementos anteriores.

Torre y muralla eran los elementos principales de la fortificación medieval, pero ¿había una muralla en Verín en época medieval jalonada por torreones? Por los datos obtenidos hasta el momento, parece que no. Las únicas referencias anteriores a su abaluartamiento ${ }^{27}$ hablan de una fortificación mal trazada ${ }^{28}$ o de una trinchera sola y de mala calidad. En ningún caso se alude a un amurallamiento previo. Todo apunta a que en Verín existiesen una serie de torreones localizados estratégicamente en lugares de

27 Relativas a los años 1644 y 1645 (Soraluce Blond, 1985: 191-192).

28 Término empleado tal vez porque no respondía a los nuevos planteamientos de la fortificación abaluartada. acceso a la villa y, tal vez, alguna trinchera, aunque posiblemente éstas fuesen posteriores a los torreones, una defensa escasa para los nuevos tiempos que se avecinaban, sobre todo una vez iniciada la guerra con Portugal en el año 1640 .

"Com a passagem da Idade Média para a Idade Moderna, assistimos a todo um complexo de adaptaçôes, mudanças e inovaçôes que vâo, necessariamente, levar à passagem da 'arte' de defender à ciência da fortificaçâo." (PEREIRA, 1994: 38).

La necesidad de mejorar la fortificación de Verín, que debe adaptarse a los nuevos tiempos, debió suponer un importante impacto urbanístico. Hay que tener en cuenta que frente a la defensa medieval, que aunque condiciona a las ciudades también acompaña su desenvolvimiento y crecimiento, la fortificación moderna determina enormemente el desarrollo de éstas, de ahí que muchas de las defensas acaben finalmente desapareciendo una vez consideradas inútiles, como es el caso de Verín en el siglo $\mathrm{xix}^{29}$.

En cuanto a la defensa de la frontera, la pregunta que cabría formularse era qué papel tendría Verín dentro de la fortificación transfronteriza. Es evidente que el valle de Monterrei era uno de los accesos principales desde el SE a Galicia. Es en esta zona, y concretamente desde Portugal, por donde se localiza un acceso que desde Chaves penetra por Verín en su camino hacia la ciudad de Ourense. El emplazamiento del Castillo de Monterrei contaba con unas defensas naturales que habían sido reforzadas en épocas medieval y moderna por distintas líneas de muralla, que combinan aún en la actualidad varios sistemas distintos de fortificación, las murallas medievales jalonadas por torreones circulares y dos líneas de murallas abaulartadas combinadas con otras construcciones (como la atalaya situada al NW o el fuerte de San Salvador) u otras defensas realizadas en tierra.

El caso de Verín difiere bastante del de Monterrey, ya que se localiza en una zona llana. Es precisamente por ello y por su situación a los pies de este castillo por lo que creemos que debe considerarse necesaria su fortificación en un periodo en el que las luchas entre España y Portugal son constantes, y concretamente esta zona es atacada de forma permanente durante la Guerra de Restauración Portuguesa e incluso con posterioridad a ésta.

\footnotetext{
${ }^{29}$ En palabras de Pereira "[...] a fortificaçâo abaluartada vai modificar a ideia de cidade, vai transformar a cidade num apêndice militar, tal como afirma Dürer. Era a cidade planeada, em que a fortificaçâo funcionava como uma 'camisa de forças' a contrapor-se à cidade medieval em que, no dizer de Braudel, 'a muralla era uma cinta por medida'» (id.: 36).
} 
Verín funcionaría como una primera defensa del Castillo de Monterrei en el paso hacia éste sobre el río Támega, además de servir, con motivo de la escasez de espacio en Monterrei, de zona tanto de alojamiento como de avituallamiento de las tropas.

Gracias a la combinación de los trabajos realizados en este proyecto, se ha podido recuperar un sistema fortificado más complejo que el que hasta el momento se conocía para esta zona, que corresponde claramente a los planteamientos de la fortificación abaluartada: en el valle, protegiendo el acceso a Monterrei desde Portugal y la Meseta castellana, se localiza Verín, que se abaluartúa en este momento, aunque debe adaptarse a la existencia de una estructura urbana anterior. Ya en la dorsal, se emplaza en el extremo SE el castillo de Monterrei, el cual se dota en este momento de nuevas líneas de muralla abaluartadas que protegen la anterior fortificación medieval y amplían la estructura defensiva del castillo hasta la rotura de pendiente antes del descenso de la dorsal hacia el valle. Hacia el NW del castillo, en una zona más deprimida, un collado situado entre el propio castillo de Monterrei y el Alto de San Salvador, se localiza la Atalaia desde la que se domina visualmente la zona de acceso desde Portugal. Finalmente, en el Alto de San Salvador, se ha documentado otra estructura de planta estrellada con cinco baluartes localizada en el punto más elevado de la dorsal, desde el que se tiene un dominio visual de todo el valle.

Una vez finalizada la Guerra con Portugal, la preponderancia de Monterrei fue decayendo a favor de Verín, de hecho actualmente Monterrei está deshabitado. La cantidad, variedad y clase de oficios mencionados en el Catastro de Ensenada, además de las alcabalas y arriendos de la villa, es indicativo de que Verín era una villa de cierta entidad en la provincia y, sobre todo, en el entorno inmediato, la cual, frente a la primacía de Monterrei en épocas anteriores, fue ganando en importancia tanto por el éxodo poblacional producido desde el castillo hacia las villas del entorno, como Verín o Pazos, como por la mayor posibilidad de crecimiento del segundo frente al primero, a lo cual contribuyó su emplazamiento.

Varios han sido los productos explotados en este valle a lo largo de las edades medieval, moderna y contemporánea, como la explotación del estaño o de las aguas termales, los productos de huerta o el cultivo de la vid. Nos interesa este último especialmente por la incidencia que tiene en el solar objeto de estudio, ya que en él se emplaza una bodega cuya primera fase se remonta a mediados del s. XIX y que se encuentra en perfecto estado de conservación. En este sentido, son tres los elementos que creemos deben destacarse desde el punto de vista patrimonial en este trabajo: los restos del torreón bajomedieval, los restos del baluarte de época moderna y la bodega de época contemporánea.

Así, y respondiendo a la segunda cuestión que se planteaba al inicio de estas conclusiones, se considera que los tres deberían conservarse por la significación que han tenido en la historia de la villa, no digamos los dos primeros, $y$, sin lugar a duda, revalorizarse, divulgando entre los vecinos su conocimiento y reservando para ellos un uso, tal vez, cultural.

\section{Bibliografía}

1887, Ordenanzas Municipales del Ayuntamiento de Verín, Verín.

Andrade Cernadas J. M., Días Tie M. y Pérez Rodríguez F. J., 1995, O Tombo de Celanova: Estudio introductoria, edición e indices (ss. IX-XII), Santiago de Compostela.

Blanco Rotea R. y García Rodríguez S., 2005, Paisaje arquitecturado y arquitectura en el paisaje: la fortificación del territorio en Época Moderna en el Baixo Miño, Revista electrónica ArqueoWeb, 7 (2) (Sept. / Dic. 2005), http:/ /www.ucm.es/info/arqueoweb/.

Carreras Candi F. 1980, Geografia General del Reino de Galicia, Volumen XI, Tomo II: Vicente Risco, La Coruña.

Dasairas Valsa X., 2008. Libro Guía de Monterrei, Verín.

Fernández Alonso B., 1888, Carta de Fuero de la Villa de Verín, Galicia Diplomática, Año III, No 32.

Fernández Alonso B., 1893, Guerra Hispano-Lusitana, Orense

Ferreira Priegue E., 1988, Los caminos medievales de Galicia. Boletín Auriense, Anexo 9, Ourense.

García Álvarez M. R., 1964, Un documento interesante para la historia de Galicia, Cuadernos de Estudios Gallegos, Tomo XIX, fascículo 59, pp. 355-368. Licenciado Molina, 1550 (2003), Descrición do Reino de Galicia, Noia.

Madoz P., 1894, Diccionario geográfico Estadístico Histórico de España y sus Posesiones de Ultramar, Tomo XV.

Pereira M., 1994, Da torre ao baluarte, En TÁvora F. ET ALLI., 1994, A Arquitectura militar na expansâo portuguesa. Exposiçao, Porto, Castelo de S. Joâo da Foz (Junho-setembro de 1994), pp. 35-42, Lisboa.

PORRAS GIL C., 1995, La organización defensiva española en los siglos XVI-XVII desde el Río Eo hasta el Valle de Arán, Valladolid.

RodríGUEZ-VILlasANTE PriETO J. A., 1984. Historia y tipología arquitectónica de las Defensas de Galicia. Funcionalidad, forma y ejecución del diseño clasicista. Coruña: Ed. do Castro.

SanZ Molina S. E., 2002, Tres fortificaciones en nueva España. Estudio arquitectónico-constructivo, Universidad Politécnica de Cataluña, Tesis doctoral, Extraída http://www.tdx.cesca.es/TDX-1031102-125229/\#documents.

SoraluCE Blond J. R., 1985, Castillos y fortificaciones de Galicia. La arquitectura militar de los siglos XVI-XVIII, La Coruña.

Taboada Chivite J., 1947, Monterrey: Resumen histórico y arqueológico, Boletín del Museo Arqueológico Provincial de Orense, Tomo III, pp. 3-19.

Taboada Chivite X., 1949, Verín y sus murallas, Boletín de la Comisión de Monumentos de Orense, Tomo XVII, 1, pp. 61-72.

Recibido: 16 de septiembre de 2008 Aceptado: 13 de enero de 2009 